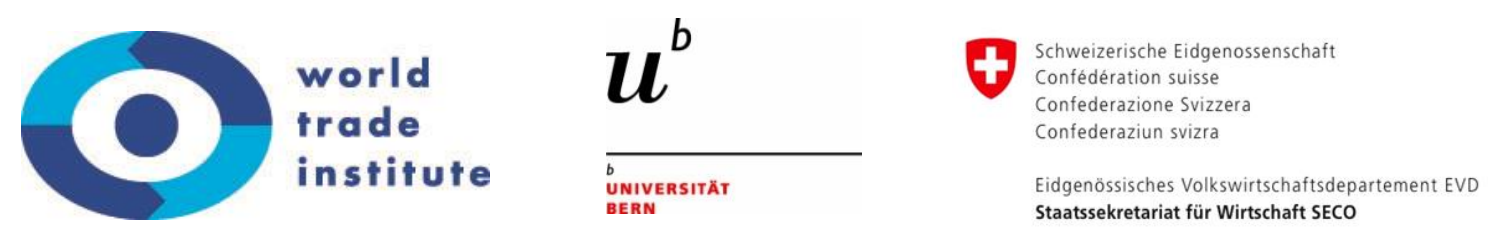

Working Paper No 17/2017 | December 2017

\title{
The Pacific Alliance in search for a financial integration: so close and yet so far
}

\author{
Manuel Monteagudo \\ Pontificia Universidad Católica del Perú \\ manuel.monteagudo@bcrp.gob.pe
}

This paper develops an analysis of how macro-economic convergence among Mexico, Colombia, Peru and Chile has translated into a non-intentional institutional and constitutional similar order, in areas as important as fiscal and monetary stability. This current reality opens many possibilities for a deep financial integration and regulatory cooperation, which are aspects not sufficiently reflected in the Treaty and the additional Protocol. In fact, these instruments have followed the standard of previous Free Trade Agreements (FTAs) under the NAFTA model on financial services treatment, which does not fit adequately with the objective of creating a free trade zone based on the free movement of capital and financial services. An example of this reality is the timid development of mutual recognition of financial service authorizations in FTAs, contrasting the technical agenda of future developments in the Pacific Alliance. In that context, this paper offer some specific proposals for the peculiar institutional construction of the Pacific Alliance and regulatory cooperation (based on the soft law experience of partners and the levels of convergence already obtained) and to review eventual consistency problems between financial integration and other international commitments of partners.

Research for this paper was funded by the Swiss State Secretariat for Economic Affairs under the SECO / WTI Academic Cooperation Project, based at the World Trade Institute of the University of Bern, Switzerland.

SECO working papers are preliminary documents posted on the WTI website (WWW.Wti.org) and widely circulated to stimulate discussion and critical comment. These papers have not been formally edited. Citations should refer to a "SECO / WTI Academic Cooperation Project" paper with appropriate reference made to the author(s).

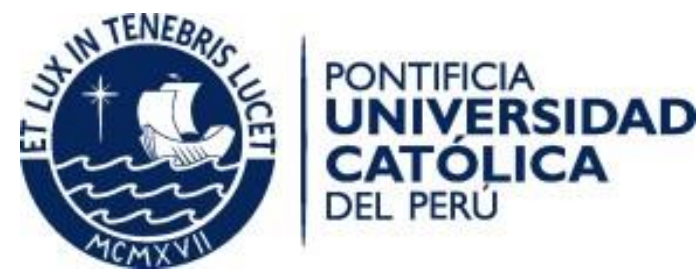




\title{
"The Pacific Alliance in search for a financial integration: so close and yet so far"*
}

\author{
Manuel Monteagudo ${ }^{* *}$
}

\section{Introduction}

The economic integration of Latin American countries is an old project conceived during the first years of independence from Spain. Since the Congreso Anfictiónico de Panamá (1826), ${ }^{1}$ the route to integration has been revived at different moments of history with varying intensity. The Andean Community (Comunidad Andina, CAN), the Common Market of the South (Mercado Común del Sur, MERCOSUR), the Central American Integration System (Sistema de Integración Centroamericana, SICA), the Union of South American Nations (Unión de Naciones Suramericanas, UNASUR), and the Pacific Alliance (Alianza del Pacífico) are the contemporary expression of that original aspiration.

\footnotetext{
* The author would like to express his gratitude to the State Secretariat for Economic Affairs (SECO) and the World Trade Institute (WTI), in particular its Academic Cooperation Project, for supporting this research project.

** Doctor in Laws, Université de Paris I, Panthéon-Sorbonne; LLM, University of Houston; BA, Pontifical Catholic University of Peru (PUCP). Currently General Counsel of the Central Bank of Perú and Professor of

International Law at PUCP. The author expresses his special recognition to Henry Zevallos and Angela Galvis, LLM candidates from the PUCP, and Beatriz Aguedo and Erick Vargas, JD students from the PUCP, for their valuable support in researching the jurisprudential and legal sources for this work. The views expressed in this article are the sole responsibility of the author. (Final edited draft dated 31November 2017)

${ }^{1}$ In 1924, Simon Bolivar called to new independent republics to gather in a Congress in Panama with the goal of forming a Confederation of states that included defense, republic and institutional common commitments.

Preferential regional commerce was in the agenda of the project of confederation, based on previous negotiations. Germán A. de la Reza, "El Congreso Anfictiónico de Panamá (1826). Determinaciones Germán

A. de la Reza, "El Congreso Anfictiónico de Panamá (1826). Determinaciones hispanoamericanas de su desenlace," pp. 189, 190, 209, Revista de Historia de América No. 134 (Jan. - Jun., 2004). See also Nathalie Blasco, «Présence du mythe unitaire bolivarien dans les traités d'alliance inter-latinoaméricains au XIXe siècle » Caravelle (1988-) No. 85, Grandes plantations d'Amérique latine: Entre rêve et commerce (Décembre 2005), pp. 185-204.
} 
And even if Latin American regionalism over the last twenty years has moved mostly towards economic liberalization under an "open regionalism," this tendency has not been accompanied by a supranational institutional arrangement equivalent to the European Union. ${ }^{3}$ From the perspective of international economic law history, it is interesting that the absence of such an institutional arrangement has not prevented a substantial level of macroeconomic convergence —under soft law mechanisms - 4 among countries like Mexico, Colombia, Peru, and Chile. This is precisely the point of departure of the economic integration process under the Pacific Alliance; i.e., the establishment of an area of regional integration, ${ }^{5}$ in the Framework Agreement, with the explicit objective of building " $a$ zone of deep integration to develop progressively the free circulation of goods, services, capitals and persons. ${ }^{6}$

Macroeconomic convergence among Mexico, Colombia, Peru, and Chile has translated into a similar nonintentional constitutional order in areas as important as fiscal and monetary stability (principles of fiscal responsibility and central bank independence), financial integration, and regulatory cooperation, which are not reflected sufficiently in the Framework Agreement and the Additional Protocol. ${ }^{7}$ In fact, these instruments have followed the standard texts of previous Free Trade Agreements (FTAs) under the North

\footnotetext{
${ }^{2}$ The term open regionalism ( « regionalismo abierto ») is employed in the second paragraph of the Preamble of the Framework Agreement of the Pacific Alliance as follows: "Decided to strengthen the different integration schemes in Latin America, as spaces of accordance and convergence, oriented to promote the open regionalism that efficiently insert all the parties in the globalized world and interrelate them other initiatives of regionalization" (unofficial translation based also in analogous texts of Free Trade Agreements as all of the reference to Pacific Alliance instruments). See reference to L. Burgorgue - Larsen, « Le Fait Régional dans la Juridictionnalisation du Droit International » in SFDI, La juridictionnalisation du droit international, Paris, Pedone, 2003 in «La Jurisprudence des Tribunaux des Organisations d'Intégration Latino-Américaines », Annuaire Français de Droit International LI - 2005 - CNRS Éditions, Paris, pp. 633 634 (Chronique coordonée par Patrick Daillier, Myriam Benlolo-Carabot, Nadine Susani, Anne-laure VaursChaumette, Chronique No 1).

${ }^{3}$ See a comparative reflection between the European Union and the Latin American liberalization in Manuel Monteagudo, "Construcción europea y liberalización económica en América Latina: desafíos comunes en la evolución del Derecho internacional económico," Cuadernos europeos de Deusto, No 43 (España, 2010).

${ }^{4}$ See some examples of the use of soft Law in Latin America in Manuel Monteagudo, "Evolución del Derecho Internacional Económico en América Latina: ¿la Liberalización es solo Económica? en "Estado y Futuro del Derecho Económico Internacional en América Latina," pp. 75-87 (Universidad Externado de Colombia, 2013).

5 Article 1 of the Pacific Alliance first Treaty and in Spanish, "Acuerdo Marco de la Alianza del Pacífico," signed on June 6, 2012 (already ratified by county members). We will refer it as the Framework Agreement.

${ }^{6}$ Article 3.1 (a) of the Framework Agreement.

${ }^{7}$ In Spanish the additional Protocol is called, "Protocolo adicional al Acuerdo Marco de la Alianza del Pacífico" and it was signed on February 10, 2014 (already ratified by county members)
} 
American Free Trade Agreement (NAFTA) model on financial services treatment, which does not necessarily imply the creation of full financial integration mirroring the European common market. Aspects like mutual recognition as a pivotal element for banking integration are only established in general terms; ${ }^{8}$ and regulatory exceptions for prudential, monetary, and exchange purposes are established following the General Agreement on Trade in Services (GATS) and FTA models. ${ }^{9}$

Thus, the timid development of international instruments under the Pacific Alliance has been overcome by initiatives that are well justified in a relatively homogeneous group of countries, like the integration of local stock exchanges (Mercado Integrado Latinoamericano, MILA), arranged by private participants and fully supported by local regulators. In fact, MILA has already pressed for some regulatory convergence and mutual recognition, showing the possibilities of deeper financial integration like in the European

Union and the Association of Southeast Asian Nations (ASEAN). In fact, at some levels, ASEAN departed from a lower stage of integration than Latin America. ${ }^{10}$

As a result of economic liberalization under stabilization programs promoted by international economic organizations like the International Monetary Fund (IMF), the World Bank, and the Bank for International Settlements (BIS), among others, Pacific Alliance members considerably open to the world economy without having developed specific mechanisms for financial integration in Latin America; and the problem now is that, after the recent financial global crisis, several global banks have withdrawn from the region $^{11}$ and no major European or American banks have filled the void. ${ }^{12}$ In general, even

\footnotetext{
${ }^{8}$ Article 11.2 of the Additional Protocol of the Pacific Alliance

${ }^{9}$ Article 11.1 the Additional Protocol of the Pacific Alliance

10 "Except for the financial centers of Hong Kong SAR and Singapore, the degree of financial integration of many Asian economies is below the level predicted by the model for all economies, and in several cases falls behind the norm for Latin America and Eastern Europe." Geert Almekinders, Satoshi Fukuda, Alex Mourmouras, Jianping Zhou, "ASEAN Financial Integration," p. 8, IMF Working paper WP/15/34 (February 2015)

${ }^{11}$ Luc Eyraud, Diva Singh, and Bennett Sutton, 5 "Benefits of Global and Regional Financial Integration in Latin America," (IMF Working PaperWestern Hemisphere Department, January 2017). Bilateral and multilateral initiatives to increase the transparency of the international financial system have also contributed to a loss of correspondent banks in Latin America. U.S. agencies' enforcement actions against breaches of compliance with domestic regulations on trade and economic sanctions, tax evasion, and anti-money
} 
laundering/combating the financing of terrorism, as well as other post-global financial crisis developments, 
Latin American banking systems that are not strongly integrated have recently built tight links with advanced economy banking systems, from which shocks may emanate. ${ }^{13}$ Peru and Chile, for example, offer a relatively high degree of global openness that is offset by the lack of regional integration of their respective financial markets. ${ }^{14}$

This article highlights the institutional convergence that Pacific Alliance members have reached in monetary and fiscal policies, in contrast with the general principles of financial integration provided by the treaty instruments and local legislation (section I). An analysis is also proposed of some major elements of financial integration focused on the banking sector, in order to identify some consistency problems of the legal framework of the Pacific Alliance and suggest solutions for the future agenda (section II).

The high degree of macroeconomic convergence of Pacific Alliance members in some aspects can be considered a starting point that is significantly more developed than the initial stages of the Single Market Program (SMP) in banking and financial services (1992) in the European Union. Gardener, Molyneux, Mooere and Winters point out that prior to start of the SMP the regulatory structure and competitive environment of European banking and financial system resembled, to varying degrees, those of many developing countries, including low banking standards in key areas like credit risk appraisal and loan management, weak prudential supervision, and weak internal controls and risk management. ${ }^{15}$ Today, many Latin American countries, especially the Pacific Alliance members, are well in the path of Basel Committee standards, although with some

have led international banks operating under US regulations to withdraw from activities seen as high risk. Iulia Ruxandra Teodoru, "Barriers to Integration in Banking in IMF, 53, "Financial Integration in Latin America, a New Strategy for a New Normal (Ch. Enoch, W, Bossu, C. Caceres and D. Singh eds. 2017).

${ }^{12}$ Id. at ix.

${ }^{13}$ IMF, "Financial Integration in Latin America" 32 (Staff Report, March 2016). "Bank linkages with advanced economies outside the region-in particular, Canada, Spain, UK, and the United States-are relatively important... an asset-side shock to these advanced economies' banking systems could have a sizeable impact on the availability of foreign credit to Latin American countries. A shock to any of the Latin American banking systems would likely have small direct spillovers on to other countries in the region due to limited intraregional cross-border banking exposures." Ibid.

${ }^{14}$ See Luc Eyraud, Diva Singh, and Bennett Sutton, Supra note 11 at 15.

${ }^{15}$ E.P.M. Gardener, P. Molyneux, B. Moore and L.A. Winters, "The Impact of the Single Market Programme on EU Banking: Select Policy Experiences for developing Countries," pp. 236 - 237 in World Trade Organization and World Bank, The Internationalization of Financial Services - Issues and Lessons for Developing Countries (S. Claessens and M. Jansen eds.) 2000 Kluwer Law International 
differences in the speed of implementation, ${ }^{16}$ showing relative robustness and resilience after the last global financial crisis ${ }^{17}$ and creating an environment for the integration of financial markets that can permit regional banks to cover the space left by global banks. The financial crisis and the increased regulatory oversight have led some global institutions to reduce their cross-border activities and pull back into their core markets. ${ }^{18}$ The Latin America economic space is now in front of a new opportunity to evolve.

\section{Living an extraordinary momentum for convergence in institutional economics?}

Pacific Alliance members have reached such an extraordinary level of macroeconomic convergence that one could imagine that the Framework Agreement and the Additional Protocol should have produced more explicit commitments on financial integration. Average inflation in the 1980s was $1421 \%$ in Peru, $70 \%$ in Mexico, $24 \%$ in Colombia, and $22 \%$ in Chile. In contrast, the overall average inflation at the end of 2015 was just $3.6 \%$. On the fiscal front, after a period of structural fiscal deficits in the 1980s, at the end of 2015 the overall average was $-3.1 \%{ }^{19}$ The debt problem of the $1980 \mathrm{~s}$ has also been overcome. Chile's public debt was $77 \%$ of GDP in 1990, ${ }^{20}$ and around $16 \%$ in 2015 . Peru's experience was similar, with its debt ratio dropping from $56 \%$ in 1990 to $31.6 \%$ in 2015 (far lower than in the European Union or the U.S). ${ }^{21}$ External robustness is also reflected in the level of international reserves, which as of 2015 had multiplied by 15 from an average of US $\$ 5.4$ billion in $1990 .^{22}$ The region's overall macroeconomic stability is reinforced by

\footnotetext{
${ }^{16}$ Brazil and Mexico lead the region in the implementation of Basel III, closely following the international timeline. Peru is next, while Chile and Colombia have taken a more gradual approach. Colombia has enhanced its capital measure, bringing it closer to the Basel III definition. Iulia Ruxandra Teodoru, "Barriers to Integration in Banking in IMF, "Financial Integration in Latin America Supra Note 11 at 52.

${ }^{17}$ R. Lastra and E. Cendeño-Brea, "Latin American Financial Reform," 25 (manuscript 2012).

${ }^{18}$ Luc Eyraud, Diva Singh, and Bennett Sutton, Supra Note 11 at 23.

${ }^{19}$ According to last IMF Article IV reports the deficit fiscal in Mexico is estimated 1.8\% (2017), in Colombia reported 1.6\% (2015), in Peru estimated 1.4\% (2017) and in Chile reported 1.7\% (2015).

${ }^{20}$ Alexandre Tombini, Rodrigo Vergara and Julio Velarde, "Growth, Stability, and Prosperity in Latin America," 29 (Group of thirty Occasional Paper No. 91, October 2015)

${ }^{21}$ According to last IMF Article IV reports the ratio public debt/GDP in Mexico was reported $58.4 \%$ (2016), Colombia 39.7\% (2015), Peru 31.6\% (2016) and Chile 19\% (2015)

${ }^{22}$ According to last IMF Article IV reports international reserves of Mexico has been estimated in US \$ 212 billion (2017), Colombia US \$ 114 billion (2015), Peru US \$ 62.1 billion (2017), and Chile US \$51.288 billion.
} 
its high degree of openness and the number of FTAs signed with the world's main actors (the U.S., the EU, Japan, and China).

Monetary and fiscal stability, already sound in the Pacific Alliance region, is considered one of the most effective engines for financial integration. Financial integration and the building of a common capital market in the European Union, as a new stage of integration, followed the consolidation of monetary stability through the European Monetary System and frequent calls for unifying principles on fiscal responsibility. ${ }^{23}$ However, the peculiarity of this process among Pacific Alliance members is the fact that macroeconomic figures have been translated into constitutional and legal principles in each member, following the implementation of international standards from the international economic organizations where they are developing an active engagement. As in the monetary domain, the harmonization of fiscal rules under international standards or common rules is a decisive point in economic integration. ${ }^{24}$ However, even though Pacific Alliance treaty instruments were negotiated in this converging context, they follow generalities that are already established in the General Agreement on Trade in Services (GATS) and FTAs signed by member countries with third parties, rather than providing specific guidelines for financial integration.

\section{a. Institutional (Monetary and Fiscal) Convergence of the Pacific Alliance in the Era of Soft Law}

As part of the worldwide trend towards ensuring central bank independence, ${ }^{25}$ since the end of the 1980s many Latin American countries amended their central banks' legislation in

\footnotetext{
${ }^{23} \mathrm{An}$ important lesson that has emerged from Europe is that monetary and financial integration without fiscal or political integration is fraught with danger, especially when member countries are highly heterogeneous in terms of fiscal discipline, export competitiveness, institutional advancement, and other macrocritical dimensions. Geert Almekinders, Satoshi Fukuda, Alex Mourmouras, Jianping Zhou, Supra note 10 at 26.

${ }^{24}$ See E. Baltensperger and N. Herger in "Development and Stability in the Nexus between Trade and Finance", The prospects of International Trade Regulation, from Fragmentation to Coherence, p. 412 (T. Cottier \& P. Delimatsis) (Cambridge 2011).

${ }^{25}$ M. Monteagudo, Neutrality of Money and Central Bank Independence, in International Monetary and Financial Law the Global Crisis, p. 495 (Oxford University Press, UK, 2010). See also generally MANUEL MONTEAGUDO, LA INDEPENDENCIA DEL BANCO CENTRAL, 311-14 (Banco Central de Reserva del Perú, Universidad del Pacífico and Instituto de Estudios Peruanos, 2010).
} 
order to consecrate monetary stability as their main goal, as well as governance independence, independence in the conduct of monetary policy, prohibition or limitations to finance the government, and accountability. This general trend was followed by Chile (1989), El Salvador (1991), Argentina (1992 and 2002), Colombia (1992), Jamaica (1992), Nicaragua (1992 and 1999), Venezuela (1992 and 1999), Ecuador (1992 and 1998), Peru (1993), Mexico (1993), Bolivia (1995), Costa Rica (1995), Uruguay (1995), Paraguay (1995), Honduras (1996 and 2004), Guatemala (2001), and the Dominican Republic $(2002) .^{26}$

In fact, a decisive legal aspect of central bank independence is the fact that its consecration is recognized at the constitutional level as part of the rule of law. That is the original conception of the social market economy in the 1920s —also known as the German ordoliberalism - which places monetary stability and central bank independence as pillars of the economic constitution. ${ }^{27}$ In terms of the distribution of State's power attributions, central bank independence implies a separation of powers ${ }^{28}$ because sovereign attributes (monetary powers) are attributed in favor of a public body which is not part of the government. In this line of thought, the Constitutional Tribunal of France, following the French centralized administrative tradition, understood in 1993 that the European central bank independence recognized by the Maastricht Treaty should imply an amendment of its constitutional regime. ${ }^{29}$ And in countries like the U.S., even though central bank independence is not expressly established by the Federal Constitution, public opinion fully supports that status as part of the U.S. economic order. ${ }^{30}$ The expressed recognition of

\footnotetext{
${ }^{26}$ Id. at pp. 26-27 and also Committee on International Monetary Law (MOCOMILA), Report for the INTERNATIONAL LAW ASSOCIATION (WASHINGTON CONFERENCE, 2014) in http://www.mothe European Constitution comila.org/publication/2014-mocomila-washington-report.pdf

${ }^{27}$ See more about the German ordoliberalism in MANUEL MONTEAGUDO Supra note 25 at pp. 353-368. Social Market economy is referred by Article 3.3 of the European Union Treaty (as it is the case of article I-3 of the non-approved texts European Constitution.

${ }^{28}$ Article 16 of the Declaration of the Rights of Men and Citizens (1789) established that every society in which the guarantee of rights is not secured and the separation of powers is not clear does not have a Constitution.

${ }^{29}$ Decision of the Conseil Constitutionnel of 9th April 1993 (JPC, 92, 2, 21853)

30"It appears safe to say, for example, that the US Federal Reserve Board, although not part of the explicit constitution, is sufficiently embedded in American life to have a constitution-like statutes, in the sense that, absent economic disaster, any attempt significantly to reduce the independence of the Fed would be politically unthinkable. In an environment of illegal or arbitrary extractions, there is little benefit to a guarantee of price-level stability since no political deal has durability in any event." MILLER G.P., "An
} 
central bank independence by national constitutions in countries with a civil law tradition — as in the case of Pacific Alliance members - is a necessary condition to make them operate efficiently. Classical political bodies (Congress and Government) are confined to modifying or restricting central bank independence if their basic elements are clearly identified in the Constitution, constitutional or organic laws, and even in jurisprudence.

The Constitutions of Mexico, Colombia, Peru and Chile recognize generally the principle of central bank independence and provide specific limitations or prohibitions on credit to the government. Article 28 of the Mexican Constitution establishes that the State shall have a central bank that shall be autonomous for the exercise of its functions and management. Its prior goal shall be to promote stability of purchasing power of national currency, strengthening by this way the national development in charge of the State. None authority shall mandate the bank to accord financing. In the case of Colombia, article 371 of the Constitution establishes that the Bank of the Republic shall perform central bank functions. It will be organized as a moral person of public law, with administrative, patrimonial and technical autonomy under its own legal regime, and regarding the credit to the government article 373 disposes that Credit operations in favor to the government shall require the unanimity of Board members unless the case of open market operations. In no case Congress will mandate quotas of credits in favor of the State or private persons. The Peruvian and Chilean Constitutions follow the same pattern with even more restrictions on credit. Article 84 of the Peruvian Constitution establishes that the Central Bank is a moral person of public law. It enjoys autonomy according to its organic law... The Bank is prohibited to accord credit to the Treasury, with the exception of the purchase in the secondary market of Treasury bills subject to the limits established in its organic law." According to article 108 of the Chilean Constitution, it shall exist an autonomous organism with own patrimony, technical character, named central bank, whose composition, organization, functions and powers shall be determined by a constitutional organic law, and article 109 that no public expense or loan shall be financed by direct or indirect loans the central bank. Despite that, in case of external war or the risk of it as qualified by the

Interest-Group Theory of central bank independence", Chicago: The Journal of Legal Studies, Vol. XXVII(2), June 1998, p. 451. 
National Security Board, the Bank will be able to obtain, accord or finance credits to the State and public or private entities.

Even though constitutional texts show some differences, they are evidence of a significant level of constitutional convergence. ${ }^{31}$ The principle of autonomy or independence is well established; and in countries like Colombia, where the Board of Directors of the central bank is led by the Ministry of Finance; ${ }^{32}$ the Constitutional Tribunal has reaffirmed central bank independence on different occasions. One of the most significant decisions was reached in 1993, when the Tribunal stated that the Banco de la República is a body created for the service of the functional imperative of ensuring a "healthy" currency, and therefore free from political influence and not part of the government. ${ }^{33}$

On fiscal stability and responsibility, since the end of the 1990s Latin America has followed a similar approach to central bank independence, introducing specific legislation on fiscal transparency and responsibility, including limits on the fiscal deficit and public debt under the IMF code of Best Practices on Fiscal Transparency, first published in 1998 and modified in 2007 and 2014. ${ }^{34}$ By 2007 almost all Latin American countries (with the exception of the Dominican Republic, Venezuela, and Bolivia) had performed assessments under the IMF code of Fiscal Transparency. ${ }^{35}$

Pacific Alliance country members are not an exception to the trend on fiscal responsibility. ${ }^{36}$ In 2006 Mexico approved the Federal Budget and Fiscal Responsibility

\footnotetext{
${ }^{31}$ Chile and Peru rank among the most de jure independent central banks in the emerging markets' world. L. I. Jácome, E. W. Nier and P. Iman, "Building Blocks for Effective Macroprudential Policies in Latin America: Institutional Considerations,” p. 18 IMF Working Paper (July 2012). The reform towards central bank independence in Latin America has been an evolving process. In 2003, after the reform of central bank legislation, the work of Laurens, Arnone and Segalotto on central bank independence ranked already the central banks of Mexico, Colombia, Peru and Chile among the group of countries with medium score of independence. B. Laurents, M. Arnone and J-F Segalotto, "Central Bank Independence, Accountability, and Transparency (IMF 2009).

${ }^{32}$ Article 28 of the Law No 31, Law of the Banco de la República

${ }_{33}$ Paragraph 12 of the Constitutional Tribunal Decision of November 11, 1993.

${ }^{34}$ The IMF code was updated in 2007 See current version of the IMF code of Best Practices on Fiscal Transparency in http://blog-pfm.imf.org/files/ft-code.pdf

${ }^{35}$ T. Parry, "The Role of Fiscal Transparency in Sustaining Growth and Stability in Latin America, "IMF Working Paper 07/220, p. 4 (2007) (http://www.imf.org/external/pubs/ft/wp/2007/wp07220.pdf)

${ }^{36}$ Committee on International Monetary Law (MOCOMILA), Supra note 26.
} 
$L a w^{37}$ with a zero fiscal target for the public sector balance and the principle that the annual budget law must provide macroeconomic forecasts and fiscal objectives. Colombia, although already having a Semaphore Law since 1997, ${ }^{38}$ approved Law 819 (Organic Budget Rules for Fiscal Transparency and Macroeconomic Stability) in 2003, ${ }^{39}$ which established a fiscal surplus target, limits to the public debt, and a medium-term macroeconomic framework. ${ }^{40}$ The constitutional reform of 2011 provided the principle of fiscal sustainability and a fiscal rule. ${ }^{41}$ Peru approved the Law on Fiscal Prudence and Transparency in $1999^{42}$ (amended in 2003, 2007, 2013, 2016 and 2017). ${ }^{43}$ The current regime establishes that total public debt shall not be more than $30 \%$ of the GDP and a fiscal deficit target (below $1 \%$ of GDP). ${ }^{44}$ The law establishes a medium-term macroeconomic framework, as well as limits on the deficit, borrowing of sub-national governments, and spending during election years. Chile, considered one of the most fiscally transparent countries in the world even before the regional reforms, ${ }^{45}$ approved in 2006 the Fiscal Transparency and Responsibility Law, ${ }^{46}$ following the recommendations of international organizations (IMF, IDB, WB and the OECD). ${ }^{47}$

\footnotetext{
${ }^{37}$ Law published on March $30^{\text {th }} 2006$ and amended in 2007, 2008, 2012, 2014 and 2015.

${ }^{38}$ Law No. 3581997 (published on February $4^{\text {th }} 1997$ )

${ }^{39}$ Law No. 819 (July $9^{\text {th }} 2003$ ).

${ }^{40}$ See "Fiscal policy, public debt and monetary policy in emerging market economies," p. 12 (BIS Papers No 67 Monetary and Economic Department, October 2012)

${ }^{41}$ The new version of Article 334 of Colombian Constitution provides principle of fiscal sustainability for any public action executed to reach public objectives (La dirección general de la economía estará a cargo del Estado. Este intervendrá, por mandato de la ley, en la explotación de los recursos naturales, en el uso del suelo, en la producción, distribución, utilización y consumo de los bienes, y en los servicios públicos y privados, para racionalizar la economía con el fin de conseguir en el plano nacional y territorial, en un marco de sostenibilidad fiscal, el mejoramiento de la calidad de vida de los habitantes, la distribución equitativa de las oportunidades y los beneficios del desarrollo y la preservación de un ambiente sano. Dicho marco de sostenibilidad fiscal deberá fungir como instrumento para alcanzar de manera progresiva los objetivos del Estado Social de Derecho. En cualquier caso el gasto público social será prioritario. (...) La sostenibilidad fiscal debe orientar a las Ramas y Órganos del Poder Público, dentro de sus competencias, en un marco de colaboración armónica. (...))

${ }^{42}$ Law No. 27245

${ }^{43}$ Laws Nos. 27958, 29144, 30099, Decree Legislative No. 1276 and Law 30680.

${ }^{44}$ Articles 6.1a) and 6.1b) of the Decree Legislative No. 1276.

${ }^{45}$ Manuel Monteagudo, "Evolución del Derecho Internacional Económico en América Latina: ¿la Liberalización es solo Económica?, Supra note 4 at pp. 80 - 81 .

${ }^{46}$ Law No. 20128 published on 30 September 2006.

${ }^{47}$ Press release of the Ministry of Finance of September 28, 2005 in http://www.dipres.gob.cl/594/articles21088_recurso_1.pdf
} 
Monetary and fiscal stability and transparency are only part of a larger convergence in public policy aspects of Pacific Alliance country members. As mentioned, this process has been promoted from classical international economic organization (the IMF and the World Bank) that led stabilization programs in these countries through the implementation of IMF facilities, ${ }^{48}$ and also under the Financial Sector Assessment Program (FSAP) for the surveillance of financial stability and development. ${ }^{49}$

Besides that, Pacific Alliance country members have also engaged in less universal institutions and international regulatory associations. For example, Mexico and Chile are already members of the Organization for Economic Cooperation and Development (OECD) ${ }^{50}$ and Colombia and Peru have initiated their respective adherence processes. ${ }^{51}$ All of the central banks from Pacific Alliance countries have become members of the Bank for International Settlements (BIS) since the end of the $1990 \mathrm{~s},{ }^{52}$ and they are also active participants of soft law creators such as the International Organization of Securities Commissions (IOSCO); ${ }^{53}$ the EGMONT group of Financial Intelligence Units; ${ }^{54}$ the Financial Action Task Force (FATF - GAFI), established to set standards and promote effective implementation of legal, regulatory and operational measures for combating money laundering, financing of terrorism and other related threats to the integrity of the international financial system; ${ }^{55}$ the International Federation of Accountants (IFA); ${ }^{.5}$ the

\footnotetext{
${ }^{48}$ Mexico had an IMF Extended Fund Facility (EFF) in 1989 and two IMF Stand-By Facilities in 1995 and 1999. Colombia had an EFF in 1999 and SBA in 2003 (precautionary). Peru had three SBAs in 1989, 1996 and 1999 (being precautionary in 1996 and 1999) and two precautionary SBA in 2001 and 2002. Chile had a SBA in 1989. See Table 2.5 IMF arrangements in Latin America 1989 - 2004 in IMF. See, Anoop Singh, Agnès Belaisch, Charles Collyns, Paula De Masi, Reva Krieger, Guy Meredith, and Robert Rennhack, 15 (Table 2.5) "Stabilization and Reform in Latin America: A Macroeconomic Perspective on the Experience Since the Early 1990s" (IMF, February 2005)

${ }^{49}$ FSAPs analyze the resilience of the financial sector, the quality of the regulatory and supervisory framework, and the capacity to manage and resolve financial crises. Based on its findings, FSAPs produce recommendations of a micro- and macro-prudential nature, tailored to country-specific circumstances. See FSAP's content and objectives in http://www.imf.org/external/np/fsap/fssa.aspx. The last FSAP's reports on each Pacific Alliance country members

${ }^{50}$ Mexico since May 18th 1994 and Chile May 7h,2010

${ }^{51}$ Peru was formally invite don May $7^{\text {th }} 2014$ and Colombia initiated its process on May $29^{\text {th }} 2013$.

${ }^{52}$ Mexico on November 1996, Chile on May 2005, Peru on June 2011 and Colombia on 2011. See reference in BIS Press release, "BIS invites new members" 26 June 2011 (https://www.bis.org/press/p110626a.htm)

${ }^{53} \mathrm{See}$ in https://www.iosco.org/about/?subsection=membership_map

${ }^{54} \mathrm{See}$ in https://www.egmontgroup.org/en/membership/list

${ }^{55} \mathrm{See}$ in http://www.fatf-gafi.org/countries/

${ }^{56} \mathrm{Se}$ in https://www.ifac.org/about-ifac/membership
} 
International Accounting Standards Board (IASB) ${ }^{57}$ the International Association of Deposit Insurers (IADI) ${ }^{58}$ and the International Association of Insurance Supervisors (IAIS). ${ }^{59}$

This machinery of global standardization has served to create a positive environment for the economic integration of a group of countries that share a clear identification with the international economic system. As mentioned, looking at the European experience, Latin America and the Pacific Alliance have developed their "own way" to harmonize financial regulations and practices without resorting to a supranational authority. In that context, the presence of Mexico in the Financial Stability Board (FSB) following the enlargement of its structure in 2008 at the time of the international financial crisis, offers a great opportunity to Pacific Alliance country members for communicating with this influential organization ${ }^{60}$ to deepening their financial integration process.

Convergence in monetary stability and fiscal responsibility are basic premises for making progress towards financial integration if we —once again - take the European experience as a recent historical reference. In the European Union, monetary unification was a decisive phase that ushered in new processes like the banking and capital market union; but limitations and asymmetries in fiscal responsibility principles have delayed the European process in many instances. ${ }^{61}$ Thus, the Pacific Alliance should take full advantage of the institutional convergence already gained regarding these two premises.

\footnotetext{
${ }^{57}$ See in http://www.ifrs.org/use-around-the-world/use-of-ifrs-standards-by-jurisdiction/

${ }^{58}$ Mexico, Colombia and Peru are members of IADI. See in http://www.iadi.org/en/about-iadi/iadi-membersand-participants/list-of-members/

${ }^{59}$ See in http://www.iaisweb.org/page/about-the-iais/iais-members

${ }^{60}$ The FSB has become the most important mechanisms "for national authorities, standard setting bodies and international financial institutions to address vulnerabilities and to develop and implement strong regulatory, supervisory and other policies in the interest of financial stability." Source (legal documents and JIEL article) See also http://www.fsb.org/about/history/

${ }^{61}$ Precisely the EU response to the international financial crisis that started in 2007 included a package of stricter fiscal rules to strengthen the Stability and Growth Pact. See an illustrative summary of EU context and fiscal measures in René Smits, "The Crisis Response in Europe's Economic and Monetary Union: overview of legal developments," pp. 8-29 (Working Paper Series 2015 - 01 of the Amsterdam Centre for European Law and Governance) (submitted to Fordham Journal of International Law)
} 


\section{b. Is the goal of creating a deep Financial Integration Area in the Pacific Alliance realistic?}

The Framework Agreement of the Pacific Alliance is ambitious in formulating the horizon of the integration project when we consider some paragraphs of its Preamble. They refer to the Presidential Declaration of April 28, 2011, which established "an area of deep integration in search for the progressive development of the free movement of goods, services, capitals and persons" ${ }^{\prime \prime 2}$ and having as initial base or point of departure "all of the economic, commercial and integration agreements already signed by country members at the bilateral, regional and multilateral level."63 Therefore, article 3 of Framework Agreement consecrates the explicit goal of "building, in a participative and consensual way, an integrated area ${ }^{, 64}$ and commits, among their respective implementing actions, to "liberalize the exchange of goods and services, in light to consolidate a free trade zone among the parties." Article 1.1 of the Additional Protocol also provides explicitly that country members of the Pacific Alliance create a free trade zone, with the sense of article XXIV of the General Agreement on Trade and Tariffs (GATT) and article V of the General Agreement on Trade in Services (GATS) that permit WTO members to deviate from their treaty obligations as a result of having entered into FTAs, provided that they establish a significant degree of economic integration. ${ }^{65}$ These provisions offer the possibility to achieve a higher degree of regional openness without automatically granting similar treatment to the rest of WTO members, a possibility that has not been used extensively in Latin American FTAs. ${ }^{66}$ However, the Pacific Alliance should not be conceived as a mere liberalization of national economies, but a process in which such liberalization is a vehicle for building an area of deep integration. The term "deep integration" used in Pacific Alliance treaties implies an ambition that goes beyond the liberalization stage already provided in FTAs or commercial agreements.

\footnotetext{
${ }^{62}$ Paragraph 2 of the Preamble of the Framework Agreement.

${ }^{63}$ Paragraph 7 of the Preamble of the Framework Agreement

${ }^{64}$ Objective 1.a provided in article 3 of the Framework Agreement.

${ }^{65}$ M. Matsushita, T. J. Schoenbaum, P. C. Mavroidis \& M. Hahn, "The World Trade Organization Law, Practice and Policy" p. 373 (Third Edition, 2015), The Oxford International Law Library

${ }^{66}$ L. Lorenzo \& W. Bossu, " Legal Barriers to Regional Financial Integration in Latin America" in Latin America, A New Strategy for a New Normal," 109, (Ch. Enoch, W, Bossu, C. Caceres and D. Singh eds.
} 
If we look at the European common market as one of the most advanced experiences in "deep integration" of the financial sector, we can identify that the high level of regulatory harmonization and mutual recognition of licenses of local regulators are pivotal elements in its construction. In assessing financial integration in the ASEAN, the lack of mutual recognition and common disclosure requirements are also standing in the way of the creation of a common market. In this regard it is important to note that the AEC Blueprint calls for regulatory harmonization and the strengthening of policy coordination among member states. ${ }^{67}$ However, despite the "deep integration" goal enunciated in treaties, the Additional Protocol of the Pacific Alliance develops both pivotal elements, almost mirroring the texts of the FTAs under the NAFTA model, which do not have the same goal and perspective. As mentioned, the Framework Agreement recognizes in its Preamble that previous economic, commercial and integration agreements are the base for the integration process, meaning that they should be understood as a point of departure and not of arrival.

Chapter 11 of the Additional Protocol is devoted to financial services and most of its articles cover similar topics with similar language to the NAFTA model, which is not precisely an initiative for deep integration or even a common market, like previous U.S. initiatives. ${ }^{68}$ Article 11.1 starts defining financial services with a large list of financial, banking and insurance activities; Article 11.2 determines the scope of its application to measures adopted or maintained by member countries regarding: a) financial institutions of another Party, b) investors of another Party, and investments of such investors, in financial institutions in the Party's territory, and c) cross-border trade in financial services; and articles 11.3 and 11.4 recognize National Treatment and the Most-Favored-Nation (MFN) Treatment, respectively. Article 11.6 refers to cross-border trade but limited - as in the

\footnotetext{
${ }^{67}$ Geert Almekinders, Satoshi Fukuda, Alex Mourmouras, Jianping Zhou, Supra note

${ }^{68}$ The adoption of the NAFTA must be seen against the background of several initiatives undertaken during the past four decades to increase US involvement in hemispheric integration, with the ultimate goal of achieving free trade but stopping well short of any "common market" commitment. Initiatives such as the Alliance for Progress, the Caribbean Basin Initiative and the Enterprise for the Americas Initiative bear witness to the increasing recognition, by a succession of US Presidents, that elimination of cross-border obstacles to trade among American states would be beneficial. M. Van Empel and A. Mörner, "Financial Services and Regional Integration," 51 in World Trade Organization and World Bank, The Internationalization of Financial Services - Issues and Lessons for Developing Countries (S. Claessens and M. Jansen eds.) 2000 Kluwer Law International.
} 
case of the FTA between Peru and the US -69 to the provision and transfer of financial information and financial data processing and related software and advisory and other auxiliary financial services, excluding intermediation, relating to banking and other financial services. In this case, the treaty obligation does not require a Party to permit such suppliers to do business or solicit in its territory. The rest of articles of Chapter 11 also follow the basic structure of the NAFTA model. ${ }^{70}$

In order to verify the degree of development of regulatory harmonization and mutual recognition in Pacific Alliance instruments, it is very illustrative to pay attention to those Articles of Chapter 11 that, following the NAFTA model, although with slight differences, refer to local legislation. Article 11.5 provides that any Party shall permit an investor of another Party to establish under its territory a financial institution under any of the types of establishment and operation that its [local] legislation permits at the time of the establishment, without the imposition of quantity restrictions or specific requirements provided by law. ${ }^{71}$ Article 11.11 related to "Exceptions" contains the following provisions:

1. Nothing established in the Additional Protocol shall be interpreted in the sense that any Party may be impeded to adopt or maintain for prudential reasons, measures such as: (a) the protection of investors, depositors, policy-holders or persons to whom a fiduciary duty is owed by a financial institution or cross-border financial service supplier; (b) the maintenance of financial security, solvency, integrity or responsibility of financial institutions individually and cross-border financial service supplier, or (c) to guaranty the integrity and stability of the financial system.

\footnotetext{
${ }^{69}$ Article 12.5 .1 of the FTA signed between Peru and the US.

${ }^{70}$ Right to establishment (Article 11.5), Cross-Border Trade (article 11.6), New Financial Services (article 11.7), Treatment of Certain Information (article 11.8), Senior Management and Boards of Directors (article 11.9), Non-Conforming Measures (article 11.10), Exceptions (Article 11.11), Recognition and Harmonization (Article 11. 12), Transparency and Administration of Certain Measures (article 11.13), Self-Regulatory Organizations (article 11.14), Payment and Clearing Systems (article 11.15), Specific Commitments(article 11.16), Data Processing (article 11.17), Financial Services Committee (article 11.18), Consultations (article 11.19), Dispute Settlement (article 11.20) and Investment Disputes in Financial Services (article 11.21). It should be noted that Recognition and Harmonization is provided in the FTA signed by Peru and the US in Article 12.3 referred to Most-Favored-Nation Treatment. (following the FTA between the US and Peru)

${ }^{71}$ This rule is not provided in the same terms in FTA signed by Peru and the US See Article 12.4 and investment (Investment Chapter).
} 
Where such measures do not conform with the provisions of this Additional Protocol, they shall not be used as a means of avoiding the Party's commitments or obligations under such provisions.

2. Nothing in this Additional Protocol applies to non-discriminatory measures of general application taken by any public entity in pursuit of monetary and related credit or exchange rate policies. This paragraph shall not affect a Party's obligations under Article 10.8 (Performance Requirements) with respect to measures covered by Chapter Ten (Investment) or under Article 10.11 (Transfers) or 9.13 (Transfers and Payments).

3. Notwithstanding what is established in Article 10.11 (Transfers) and Article 9.13 (Transfers and Payments), as incorporated into this Chapter, a Party may prevent or limit transfers by a financial institution or cross-border financial service supplier to, or for the benefit of, an affiliate of or person related to such institution or supplier, through the equitable, non-discriminatory, and good faith application of measures relating to maintenance of the safety, soundness, solvency, integrity, or financial responsibility of financial institutions or cross-border financial service suppliers. This paragraph does not prejudice any other provision of this Agreement that permits a Party to restrict transfers.

4. For greater certainty, nothing in this Chapter shall be construed to prevent the adoption or enforcement by any Party of measures necessary to secure compliance with laws or regulations that are not inconsistent with this Chapter, including those relating to the prevention of deceptive and fraudulent practices or to deal with the effects of a default on financial services contracts, subject to the requirement that such measures are not applied in a manner which would constitute a means of arbitrary or unjustifiable discrimination between countries where like conditions prevail, or a disguised restriction on investment in financial institutions or crossborder trade in financial services, as they are covered by this Chapter. 
The four paragraphs of article 11.11 emphasize the capacity of country members to impose measures $^{72}$ that, under certain conditions, may remain immune from the integration commitments provided by treaties. Those measures are related to prudential reasons, monetary and related credit or exchange policies and the prevention or limitation of transfers for the maintenance of the safety, soundness, integrity or financial responsibility of financial institutions or cross-border financial service suppliers. In sum, the exceptions provided by article 11.11 cover any legislative and regulatory and operational action from local political bodies, banking and financial regulators and supervisors and central banks. It is interesting that the reserve of national legal and regulatory capacity is almost equal to the one provided in FTAs under the NAFTA model, ${ }^{73}$ and is inspired by the so called CarveOut exception already provided in Paragraph 2 (a) of the Annex on Financial Services of the GATS (1994), as follows: "Notwithstanding any other provisions of the Agreement, a Member shall not be prevented from taking measures for prudential reasons, including for the protection of investors, depositors, policy holders or persons to whom a fiduciary duty is owed by a financial service supplier, or to ensure the integrity and stability of the financial system. Where such measures do not conform with provisions of the Agreement, they shall not be used as a means of avoiding the Member's commitments or obligations under the Agreement. (...)."

It must be recalled that in the context of negotiations of GATT instruments, financial regulators tried to assure its capacity to regulate financial markets within the system of multilateral rules that should remove -universally- any restriction to international trade. "[w] hen the idea of including financial services in the Uruguay Round was first proposed, financial regulators were concerned about the possibility of a trade agreement interfering with their ability to regulate and supervise financial institutions. They made it clear that the

\footnotetext{
${ }^{72}$ According to GATS Article XXVIII (a), 'measure' is broadly defined as 'any measure by a Member, whether in the form of a law, regulation, rule, procedure, decision, administrative action, or any other form.' And according to GATS Article XXVIII (c), it includes, inter alia, 'measures in respect of: (i) the purchase, payment or use of a service; (ii) the access to and use of, in connection with the supply of a service, services which are required by those members to be offered to the public generally; and (iii) the presence, including commercial presence, of persons of a Member for the supply of a service in the territory of another Member.' M. Matsushita, T. J. Schoenbaum, P. C. Mavroidis \& M. Hahn, Supra note 65 at p. 564.

${ }^{73}$ Article 12.10 of the FTA signed by Peru and the US.
} 
inclusion of financial services in the GATS would be unacceptable without a specific exception for prudential regulation and supervision. As a result, the GATS would be unacceptable without a specific prudential carve-out to ensure that the opening of markets that the agreement is intended to achieve will not jeopardize prudential regulation and supervision. Now, it is taken for granted by everyone involved that such a provision is necessary whenever financial services are included in an international trade or investment agreement." "74 The GATS Carve-out exception is expressed making reference to the objectives ("prudential reasons), instead of specific types of measures that might affect commitments such as market access, different national treatment provided by the whole international instrument, ${ }^{75}$ as it happens with article 11.11 of the Additional Protocol (and FTAs), so the scope of regulatory action is quite large. Additionally, the "list" of measures for prudential reasons exposed in the GATS carve-out exception is not a "numerus clausus" provision, because its formulation is merely illustrative; the provision uses the expression "including for" 76 as also happens with article 11.11.1 of the Additional Protocol ("measures such as").

Matsushita, Schoenbaum, Mavroidis and Hahn point out that the GATS carve-out exception, in contrast to the general exceptions of GATS Article XIV, where only 'necessary' measures are allowed, covers not only 'necessary' but also 'any' prudential measures,${ }^{77}$ including day-to-day measures, ${ }^{78}$ and for some authors like Marcheti, the term, financial stability in GATS' carve-out exception might be synonymous of monetary stability. $^{79}$

\footnotetext{
${ }^{74}$ Juan Marcheti, "The GATS Prudential Carve-Out" in Financial regulation at the crossroads implications for supervision, institutional design and trade, Note 10 p. 282, (Panagiotis Delimatsis \& Nils Herger eds 2011), Wolters Kluwer Law \& Business

${ }^{75} \mathrm{Ib}$. at 289

${ }^{76} \mathrm{Id}$.

${ }^{77}$ M. Matsushita, T. J. Schoenbaum, P. C. Mavroidis \& M. Hahn, Supra note 65 at 629-630.

${ }^{78}$ Id.

${ }^{79}$ In line with Schinasi (2006), several analytical implications of this definition of financial system stability are worth highlighting. The first implication is that financial system stability is a condition sine qua non for the appropriate functioning of the real economy...The second implication is that the stability of the financial system is closely linked with monetary stability. As mentioned above, one of the basic functions of the financial system is to ensure that the economy's payment system functions smoothly. This requires that fiat (or central bank) money -and its close substitutes, such as demand deposits and other bank accounts- can adequately fulfill its role as the universally accepted means of payment, unit of account and store value. In
} 
We just mentioned that the GATS carve-out clause inspired texts in FTAs and the Additional Protocol, but also the Commercial Agreement signed by the European Union with Peru and Colombia, where Article 154 is entitled Prudential Carve-Out. ${ }^{80}$ That might explain why both the FTA and the Additional Protocol have made explicit what could be implicit regarding monetary, foreign exchange and financial policies in articles 11.11.2 to 11.11.4 (Articles 12.10. 2 to 12.10.4 of FTA), taking also into consideration the evolution of international standards of Financial and Banking regulations. As quoted, Article 11.11.2 excludes "non-discriminatory measures of general application taken by any public entity in pursuit of monetary and related credit or exchange rate policies," Article 11.11.3 excludes limitation of transfers in order to the maintenance of the safety, soundness, integrity, or financial responsibility of financial institutions or cross-border financial service suppliers, and Article 11.11.4 clarifies that country members keep their power to adopt or enforce measures necessary to secure compliance with laws or regulations that are not inconsistent with this Chapter. The Commercial Agreement signed by the European Union with Peru and Colombia also disposes of a specific exclusion in Article 159.2 for monetary and related credit or exchange rate policies. ${ }^{81}$

other words, financial stability and monetary stability overlap to a large extent. Marcheti, Supra note 74 at 289

${ }^{80}$ Article 154 of the Commercial Agreement signed by the European Union with Colombia and Peru has the following text:

Prudential Carve-Out

1. Notwithstanding other provisions of this Title or Title V (Current Payments and Movements of Capital), a Party may adopt or maintain for prudential reasons, measures such as:

(a) the protection of investors, depositors, policy-holders or persons to whom a fiduciary duty is owed by a financial service supplier; $(b)$ ensuring the integrity and stability of its financial system.

2. Measures referred to in paragraph 1 shall not be more burdensome than necessary to achieve their aim, and shall not discriminate against financial services or financial service suppliers of another Party in comparison to its own like financial services or like financial service suppliers.

3. Nothing in this Agreement shall be construed to require a Party to disclose information relating to the affairs and accounts of individual customers or any confidential or proprietary information in the possession of public entities.

4. Without prejudice to other means of prudential regulation of the cross-border supply of financial services, a Party may require the registration or authorization of cross-border suppliers of financial services of another Party and of financial instruments.

${ }^{81}$ Article 159.2 of the Commercial Agreement signed by the European Union with Colombia and Peru has the following text: 2. Nothing in this Agreement applies to activities or measures conducted or adopted by a central bank or monetary, exchange rate or credit authority or by any other public entity in pursuit of monetary and related credit or exchange rate policies. 
In the case of the second pivotal element - mutual recognition and harmonizationArticle 11.12 of the Additional Protocol (similar text to Article 12.3.2 to 12.3.4 of the FTA signed by Peru and the US) provides the following:

1. In the application of measures covered by this Chapter, a Party may recognize prudential measures of another Party or of a non-Party. Such recognition may be: (a) ) accorded autonomously;

(b) ) achieved through harmonization or other means; or

(c) based upon an agreement or arrangement with another Party or a non-Party.

2. A Party according recognition of prudential measures under paragraph 2 shall provide adequate opportunity to other Parties to demonstrate that circumstances exist in which there are or would be equivalent regulation, oversight, implementation of regulation, and, if appropriate, procedures concerning the sharing of information between the relevant Parties.

3. Where a Party accords recognition of prudential measures under paragraph 2(c) and the circumstances set out in paragraph 3 exist, the Party shall provide adequate opportunity to other Parties to negotiate accession to the agreement or arrangement, or to negotiate a comparable agreement or arrangement.

The fact that a party may recognize a prudential measure of another Party (or of a nonParty) implies that a regulatory decision or an implemented policy from one national authority will be recognized and, therefore, produce legal effects before a different national authority as a mechanism to facilitate the establishment and provision of financial services in the context of a liberalization or integration project. In both cases, recognition will be the result of a high level of harmonization of local regulations and policies; however, mutual recognition should have more possibilities to develop in a deep integration agenda as the Pacific Alliance, rather than in a mere trade liberalization commitment. Article 11.12 of the Additional Protocol, again almost mirroring FTA and UE commercial agreement models, ${ }^{82}$

\footnotetext{
${ }^{82}$ Article 158 of the Commercial Agreement signed by the European Union with Colombia and Peru, that has the following text:

Recognition of Prudential Measures
} 
proposes the different ways in which that recognition could be reached: unilaterally, by either harmonization or other means and based upon an agreement.

The fact that recognition facilitates market access may explain why in the NAFTA model this principle is provided within the article devoted to the MFN Treatment, and also justifies the obligation to provide to another party the opportunity to enjoy the same treatment or negotiate accession to the mutual recognition agreement or arrangement. Nevertheless, recognition cannot constitute a means of discrimination or a disguised restriction of trade... recognition is a process involving sensitive consideration of another country's regulation and supervision. Therefore authors construct this as a narrow obligation, not imposing the same constraint as most favored nation... As long as it is shown that the recognition is based on criteria that are not biased towards one country or another and is part of an assessment procedure following due process, the recognition may be considered to be non-discriminatory. ${ }^{83}$ But we should insist on the idea that mutual recognition plays a pivotal role in an integration process, as illustrated by the European Union, with the approval and implementation of the Second Banking Directive to allow mutual recognition of banking regulations and "home country control" of credit institutions with a head office in a European member state, but with activities in other member states by means of cross-border supply or the establishment of branches. ${ }^{84}$

1. A Party may recognize prudential measures of any other country in determining how the measures relating to financial services of that Party shall be applied. Such recognition, which may be achieved through harmonization or otherwise, may be based upon an agreement or arrangement with the country concerned, or may be granted autonomously.

2. A Party that is a party to such an agreement or arrangement referred to in paragraph 1 , whether future or existing, shall afford adequate opportunity for another Party to negotiate its accession to such agreements or arrangements, or to negotiate comparable ones with such Party, under circumstances in which there would be equivalent regulation, oversight, implementation of such regulation and, if appropriate, procedures concerning the sharing of information between the Parties to the agreement or arrangement. Where a Party accords recognition autonomously, such Party shall afford adequate opportunity for another Party to demonstrate that those circumstances exist.

${ }^{83}$ Bart De Meester, "Liberalization of Trade in Banking Services, an International and European Perspective," p. 165 (Cambridge University Press 2014).

${ }^{84}$ Ibid. 271. "In addition to harmonizing some essential regulations for authorization and exercising the business of credit institutions, the Second Banking Directive elaborated two principles that still constitute the corner stone of the internal market for banking services in the EU: the principle of 'home country control' and that of 'mutual recognition'. With respect to the first principle, the Second Banking Directive required prudential supervision of a credit institution to be performed by the home member state, subject to some exceptions where the host country could still supervise. In respect to the second principle, the Directive 
Despite the high degree of macroeconomic convergence and the deep integration vocation, Pacific Alliance treaties have left the regime of mutual recognition in general terms like any FTA. Of course this is not a limitation for developing mechanisms of rapprochement towards mutual recognition (Article 11.12 of Additional Protocol refers to them), but treaty drafters seem to have opted for a gradual path, as mentioned in Article 3.1 (a) of the Framework Agreement, ${ }^{85}$ due to some remaining legal differences among country members and the natural reaction to preserve local regulatory attributions in the absence of supranational authorities. For example, today the region has a different treatment on branches and subsidiaries of foreign financial institutions; and country members do not have any specific rules on cross-border financial services based on regional criteria. ${ }^{86}$ In Mexico, the establishment of foreign financial institutions must be made through the constitution of subsidiaries and not through foreign branches, and in Colombia the establishment of subsidiaries may be conditioned to the existence of consolidated supervision of the foreign parent company and the authorization of the home supervisor. ${ }^{87}$ By the same token, in case of liquidation of a local branch of a foreign financial institution, under Colombian, Peruvian and Chilean Law creditors who reside in the country are preferred over nonresident creditors; ${ }^{88}$ and the banking laws of Peru and Colombia require local asset maintenance to satisfy liabilities of a branch in case of insolvency of the branch or the parent company. ${ }^{89}$ In Chile, creditors of any foreign financial banks, national or foreign, shall have preference over assets placed in Chile. ${ }^{90}$

\footnotetext{
provided that a credit institution that is authorized and supervised by certain member state must be allowed by other member states to carry on their territory any of the banking services for which it was granted authorization by the home member state, as far as these services are listed in the Annex to the Directive. These services can be provided by means of cross-border service supply or by means of the establishment of a branch.” Ibid. 273

85 "a zone of deep integration to develop progressively the free circulation of goods, services, capitals and persons"

${ }^{86}$ L. Lorenzo \& W. Bossu, Supra note 66 at 107.

${ }^{87}$ Ibid.at pp $110-111$.

${ }^{88}$ Ibid. at p. 113.

${ }^{89}$ Ibid, at 116.

${ }^{90}$ Article 34 of D.F.L. No. 3 of 1997.
} 
At this point of our analysis we wonder whether member countries of the Pacific Alliance are really ready to take significant steps towards deep financial integration or they prefer to remain in the general path of liberalization.

The progressive construction of MILA can provide some signals of how member countries are able to go further, despite the generalities of treaty instruments and the diverse local treatment in some areas. MILA started in 2011 as a private sector initiative to create a platform of negotiation for national stock exchanges, where a Peruvian investor could buy Colombian or Chilean shares directly from the foreign trading platform (without the intervention of a Peruvian broker as mediator through a foreign broker). ${ }^{91}$ Today MILA has become a mechanism that integrates the four members of the Pacific Alliance, fully supported by national regulators, recognizing primary issuances authorized in each jurisdiction. Since 2009 financial market regulators of Colombia, Peru and Chile signed Memoranda of Understanding (MoU) ${ }^{92}$ to support the MILA project; and since 2015 member countries have included in their summit declarations explicit commitments towards mutual recognition. The Declaration of Paracas $(2015)^{93}$ provided the commitment to modify national regulations to implement the recognition of primary issuances in any country member for their negotiation through the integrated platform, ${ }^{94}$ which is now under implementation as reported in the Declarations of Puerto Varas (2016) ${ }^{95}$ and Santiago de Cali (2017). ${ }^{96}$ Therefore, although the Framework Agreement and the Additional Protocol provide general rules under the model of previous FTAs, they offer possibilities for moving

\footnotetext{
${ }^{91}$ Mauricio Baquero-Herrera, Legal Certainty and Financial Markets Integration: The MILA case, 19 Law \& Bus. Rev. Am. 491 (2013)

${ }^{92}$ See reference to previous MoU in the 2011 MOU signed by the Securities National Commission of Peru (CONASEV), the Financial Superintendent of Colombia and the Superintendent of Securities and Insurance of Chile in http://www.mercadomila.com/files/marcolegal/chile/1adenda-al-memorando-entendimientoreguladores-colombia-chile-y-peru-150611.pdf The Mexican Stock Exchange entered the MILA in 2014 following the commitment of the Second Summit of the Pacific Alliance of December 4, 2014. See other illustrative background of MILA in Lilian Rocca, "El Mercado de Valores en Fácil" pp. 167-181 (Fondo Editorial PUCP, 2017).

${ }^{93}$ Declaration of Paracas of July 3th, 2015

${ }^{94}$ Section A of Annex 2 the Declaration of Paracas that also included the commitment to enlarge the type of instruments to be negotiated and harmonize the fiscal treatment in agreements to avoid double imposition (See confirmation of this fiscal commitment through the signature of a multilateral agreement on fiscal treatment of pension funds in Paragraph 7 of the Declaration of Santiago de Cali of June $30^{\text {th }}$, 2017)

${ }^{95}$ The Declaration of Puerto Varas of July $1^{\text {st }}, 2016$ (Section A of Annex 2).

${ }^{96}$ Declaration of Cali of June 30 2017 (Annex 2). Paragraph 7 of Annex 2 refers to a project of MoU of financial regulators that will include a passport of funds system among the four members.
} 
further towards mutual recognition and regulatory harmonization. The feasibility of a similar development in banking regulation remains a challenge for the Pacific Alliance but, as mentioned before, its instruments should be approached as a point of departure rather than a point of arrival, after a long regional debate of some policy issues. We discuss some of them in the next section.

\section{Goals and Realities of Financial Integration}

In general, financial integration can be verified by identifying the capacity - legal and factual - of national economies to create financial assets and liabilities with foreign economies. $^{97}$ This capacity covers cross-border capital flows, foreign participation in domestic markets through the establishment of branches and subsidiaries, sharing information and practices among financial institutions or unification of market structures. ${ }^{98}$ According to Article 11.2 of the Additional Protocol, the scope and coverage of Chapter 11 on Financial Services applies to measures adopted or maintained by a Party relating to: (a) financial institutions of another Party; (b) investors of another Party, and investments of such investors, in financial institutions in the Party's territory; and (c) cross-border trade in financial services. ${ }^{99}$

Financial integration must be conceived under the prism of cross-border trade for supply and establishment. Article 11.1 of the Additional Protocol defines cross-border trade in financial services or cross-border supply of financial services as the supply of a financial service: (a) from the territory of one Party into the territory of another Party; $(b)$ in the territory of one Party by a person of that Party to a person of another Party, or (c) by a national of one Party in the territory of another Party; but does not include the supply of a

\footnotetext{
${ }^{97}$ IMF, "Financial Integration in Latin America" (Staff Report, March 2016), Supra note 13 at 15.

${ }^{98}$ Luc Eyraud, Diva Singh, and Bennett Sutton, Supra note 11 at 5. L. In line with the general practice of trade law analysis, the authors distinguish between (1) The right of cross-border establishment and (2) the right to provide cross-border services. They also analyze certain cross-border financial flows of financial firms. Lorenzo \& W. Bossu Supra note 66 at 107.

${ }^{99}$ In the FTA signed by Peru and the US this text corresponds to Article 12.1
} 
financial service in the territory of a Party by an investment in that territory. ${ }^{100}$ However, as already mentioned, there is - conceptually - a substantial difference between an integration process vis-à-vis mere liberalization (even though both processes share the prism of cross-border trade) because regulatory harmonization and mutual recognition are mandatory processes (definitive point of arrival) in the first case.

Precisely, thinking about Latin American integration in financial services, Aguirre proposed in 1996 that liberalization should involve at least five fundamental freedoms: (1) The freedom (or right) of establishment; (2) the freedom to offer financial services (preferably without being required to obtain specific authorizations from host country authorities), (3) the freedom of users to obtain financial services (without considering the nationality of the supplier or its owners); (4) the absence of foreign exchange controls that limit the free circulation of capital; and (5) the existence of a single securities market, or at least sufficiently integrated and harmonized securities markets to permit cross-border issuance and trading of all types of securities. ${ }^{101}$ It is quite interesting that, taking into account the NAFTA experience, Aguirre envisioned how a liberalization-plus process should be built in Latin America, including aspects that needed an important degree of legislative and regulatory degree of convergence as exchange controls. He already emphasized that the harmonization process must be supplemented by mutual recognition in nonessential regulatory areas and ideally (though it may be difficult) by mechanisms that facilitate coordination of at least basic macroeconomic policies. ${ }^{102}$

Considering the level of macroeconomic convergence among Pacific Alliance member countries, we would have expected the inclusion of - at least - some guidelines in the Additional Protocol regarding harmonization, mutual recognition and even the carve-out exception, other than the transfer of equal texts from FTAs. As in the case of the ASEAN agenda, which considered the creation of a Task force on the ASEAN Banking Integration

\footnotetext{
${ }^{100}$ In the FTA signed by Peru and the US this text corresponds to Article 12.20

${ }^{101}$ Ernesto Aguirre, International Economic Integration and Trade in Financial Services: Analysis from a Latin American Perspective, p. 1058, 27 Law \& Pol'y Int'l Bus. (1996)

102 Ibid. at 1072 .
} 
Framework (ABIF), some specific roadmap should be in the works to pave the way towards banking liberalization and integration. ${ }^{103}$

At the same time, while up to now macroeconomic convergence has developed voluntarily and incidentally, a sort of mandatory harmonization under the treaty framework would have implied a significant degree of transfer or relinquishment of sovereign competences. ${ }^{104}$ Pacific Alliance instruments have been cautious in clarifying that a zone of deep integration will develop — progressively — the free circulation of goods, services, capitals and persons. ${ }^{105}$ In that context, we will analyze in this Section some consistency problems that may arise during the gradual period where harmonization, mutual recognition, carveout exception and local financial stability should live together; and propose some guidelines for the future agenda of banking integration.

\section{a. Promoting Deeper Regulatory Harmonization}

In theory, if Pacific Alliance country members consolidate the path towards regulatory harmonization on prudential reasons, mutual recognition should arrive naturally. The problem is that there are different speeds in the alignment of international standards. One example is precisely the implementation of Basel III, where Chile and Colombia have taken a gradual approach, while Mexico and Peru have lagged somewhat. ${ }^{106}$ In the case of the

\footnotetext{
${ }^{103}$ See Geert Almekinders, Satoshi Fukuda and Alex Mourmouras, Jianping Zhou, Supra note 10 at 7.

${ }^{104}$ The transfer (even partial) of fiscal competences to a supranational system implies necessarily a sovereign decision with corresponding constitutional effects. International law doctrine is clear on that regard. Professor Carreau considered that the project of the European Economic and Monetary Union would imply the disappearance of economic sovereignty of country members in benefit of European political powers under a federal organization. D. Carreau, T. Flory and P. Julliard, "Droit international Économique" 442 (LGDJ 3th edition, 1993). See also P Dailier and A. Pellet, 156 "Droit International Public" (LGDJ $6^{\text {th }}$ edition, 1999) ${ }^{105}$ The terms "deep" integration and "progressively" is used in the Framework Agreement (3.1 (a)). In Paragraph 5 of the Preamble of the Additional Protocol there is also employed the term "progressively."

106 See Supra note 12. See also the PUCP LLM thesis of the candidate Jimmy Izu devoted to the implementation in Peru of Basel Standard on subordinated debt as a component of banks' capital ("Implementación en el Perú de los Estándares Internacionales de Basilea referidos a la Participación de la Deuda Subordinada como Componente del Capital Bancario"). In Section, 3.3 of his thesis, Jimmy Izu makes a comparative analysis of the implementation of Peru vis-à-vis Colombia and Chile, concluding that in this specific topic Colombia is the most advanced in implementation and Chile the worst. Chile has put the accent in Basel I.
} 
European banking integration, it would have taken decades if the process had not placed mutual recognition in parallel. ${ }^{107}$

In any case, regulatory harmonization becomes a necessity when a mutual recognition agreement is in the explicit horizon of the integration project, as has already happened with the MILA. In fact, the alignment to international standards - a priori- does not constitute an obstacle to trade. Before the approval of the Tokyo Round in 1969, the Committee on Trade in Industrial products decided to establish a working group with the purpose of examining the diverse scenarios in which standards can act as obstacles to trade and proposing possible solutions. ${ }^{108}$

The ASEAN program for regional financial integration was born from the existing standards in international financial law. ${ }^{109} \mathrm{~A}$ full banking integration, such as the one governed by the "single passport" system in the European Union, would be too ambitious for ASEAN for the next ten years. Instead, member countries proposed steps for partial banking integration over a ten year period with different timelines for each individual ASEAN member state. This is to be supported by an institutional approach based on regulatory harmonization and the strengthening of policy coordination among the ASEAN member states, in line with the principles set out in the 2008 AEC Blueprint. ${ }^{110}$ The strategy includes: (1) a two-track approach whereby states should start phasing out most of the

\footnotetext{
${ }^{107}$ Pierre-Hugues Verdier, Mutual Recognition in International Finance, 64 Harv. Int'l L.J. 55, 108 (2011)

${ }^{108}$ Humberto Zúñiga Schroder, "Harmonization, Equivalence and Mutual Recognition of Standards in WTO Law, pp. 2-3 (Wolters Kluwer) 2011. One of the 'solutions' discussed in this working group was a "code of Conduct on Preventing Technical Barriers to Trade' which later developed into the Tokyo Round Standards Code. The objective of this code was to ensure that standards, both mandatory and voluntary... are not formulated or applied in such a way as to cause unjustifiable obstacles to international trade'. To achieve this objective, the Code required adherents to use 'as a basis for their standards relevant international standards'. An initial draft of the proposed Code (concluded in December 1971) contained two important definitions: firstly, 'harmonization', as the process of making the standards of different countries or organizations the same as regards their content although their layout and format may differ.' Secondly, 'equivalence' of test methods (subsequently broadened to SPS measures and TBT technical regulations, standards and conformity assessment procedures), which involved the acceptance of test methods imposed by a particular country, provided that such methods offer an assurance of conformity with applicable standards equivalent to the procedures carried out by the country of destination. References to these two concepts were also included in the Tokyo Round Standards Code, albeit with some differences regarding the scope of 'equivalence' which now encompasses 'self-certification, test results, certificates or marks of conformity'. Id.

${ }^{109}$ Hector Danny D. Uy, “ASEAN's Legal Framework on Financial Integration," 89 Phil. L.J. 257- 259 (2015).

${ }^{110}$ Geert Almekinders, Satoshi Fukuda, Alex Mourmouras, Jianping Zhou, Supra note 10 at 15.
} 
remaining restrictions on wholesale banking, while delaying the completion of the liberalization of cross-border retail banking (deposit-taking); and (b) a three-dimensional framework (equal access, equal treatment, and equal environment) to guide the long process of financial services liberalization in ASEAN. ${ }^{111}$ In that context the harmonization of banking regulations should start with the licensing requirements and extend to cover $(i)$ bank accounting standards and disclosure requirements; (ii) minimum capital requirements; (iii) risk management; (iv) prompt corrective action (PCA) and resolution methods for failed banks; (v) restrictions on large exposure; and (vi) anti-money laundering and consumer protection regulations. ${ }^{112}$

With the level of macroeconomic convergence of country members and their engagement in international organizations that play the role of standard creators, it is possible to find some areas of financial regulation that are highly harmonized and other that are less so. Therefore it may be a priority to map and monitor the level of compliance of international standards, ${ }^{113}$ taking advantage of international mechanisms already in place such as the IMF Article IV consultations, the FSAP assessments under and the Reports on the Observance of Standards and Codes (ROSC). ${ }^{114}$ Even though total harmonization is impossible due to physical and policy differences between countries, ${ }^{115}$ a reasonable level of regulatory convergence (duly monitored) may be completed by mutual recognition.

\section{b. Mutual Recognition vis-à-vis the Carve-out Exception}

Mutual recognition implies that a regulatory decision or a policy from one national authority will be recognized in another jurisdiction, while the carve-out exception guarantees that any local measure related to prudential reasons, as well as monetary and other related credit or exchange policies will remain immune from the integration commitments. Therefore, mutual recognition and the carve-out exception seem to be

\footnotetext{
${ }_{112}^{111} \mathrm{Id}$

${ }^{112}$ Ibid. at 16.

${ }^{113}$ Harmonization and coordination of the regulatory framework, including macro prudential policies and taxation have been considered a corner stone for the IMF. Luc Eyraud, Diva Singh, and Bennett Sutton, Supra note 11 at 30 .

${ }^{114}$ See Bart De Meester, Supra note 83 at 86-87.

${ }^{115}$ Humberto Zúñiga Schroder, Supra note 108 at 97.
} 
opposed to each other. Nevertheless, both principles are recognized in liberalization schemes (multilateral, regional and bilateral), under the idea that the carve-out exception by definition should not be an anti-trade mechanism. What happens is that, even if countries keep the capacity to adopt measures for prudential reasons or seek to implement monetary and related credit or exchange rate policies, when they reach a deep level of convergence of prudential requirements and policies they will be ready to recognize (by agreement) their local licenses and authorizations.

The problem is that, if there is no incentive or a political decision for regulatory harmonization, the inertia to keep financial matters under the local sphere as part of sovereign attributes, will be well protected by the carve-out exception. The fact that today there is a trend in local financial regulators to follow international standards like those created by the Basel Committee on Banking Supervision, the IOSCO or the IAIS does not assure full compliance or a simultaneous alignment, because these mechanisms - in general - are not binding, ${ }^{116}$ but remain as soft-law commitments rather than formal treaty obligations. ${ }^{117}$ Cottiers and Krajewski precisely propose that the GATS traditional model of trade liberalization and regulation implies that liberalization is achieved through international commitments and binding rules, while regulation, left to the domestic level and without a mandatory command to harmonize. ${ }^{118}$

In addition, Marcheti points out that the capacity to adopt prudential measures, without breaching international trade commitments, is considerable because the carve-out exception

\footnotetext{
${ }^{116}$ After the last financial crisis many commentators recommend to make international financial law evolve from soft to hard law rules. See, Rosa M. Lastra, "Do We Need a World Financial Organization?", 796 - 797 Journal of International Economic Law (V.17, 2014). The IMF have initiated the debate to modify the IMF to include in article IV consultations, as part of the IMF surveillance functions to include some aspects that remain in the hands of sift law creators, such as the reform financial systems against the risk of spill over. See generally, IMF "Modernizing the Surveillance Mandate and Modalities" (Prepared by the Strategy, Policy, and Review Department and the Legal Department) March 26, 2010.

${ }^{117}$ Pierre-Hugues Verdier, Supra note 107 at 61 . “... Given these limitations [limits to uniform local regulations, carve out exemptions] individual states have generally been unwilling to open their borders to foreign financial providers based solely on compliance by their home state with such international standards." Id. at 62

118 Thomas Cottier and Markus Krajewski, "What Role for non-Discrimination and Prudential Standards in International Financial Law?," p.827 Journal of International Economic Law,2010 13(3). It is argued that the GATS does not amount to an instrument of harmonization and the WTO does not offer a suitable framework to this effect. Prudential standards therefore should be left individualized. Id.
} 
does not refer to prudential regulations but to prudential "reasons." It does not restrict the freedom of regulatory authorities with respect to the type of measures that can be applied...Rather its focus is on the objectives or the underlying reasons, rather than on the instruments used in pursuance of those objectives. ${ }^{119}$ However, that capacity is not totally open-ended $^{120}$ if we consider that GATS, FTAs, and the Additional Protocol mandate that prudential measures should not be applied in a discriminatory way. Prudential measures must be designed on the basis of prudential parameters where the quality of the supervision applied in the jurisdiction of origin of the service and service supplier, assessed in objective terms, does play a role, but they are not meant to discriminate between financial institutions merely on the grounds of their nationality. ${ }^{121}$

If the carve-out exception may not necessarily have an anti-trade approach, it cannot be a full element of financial integration, as in the case of mutual recognition. In general, mutual recognition agreements reduce the cost of exports, facilitate trade, ${ }^{122}$ and constitute a significant step towards financial integration and one of the most widespread instruments of cooperation between financial regulatory instruments. ${ }^{123}$ But again, mutual recognition is only likely to be a viable option when states reveal comparable development and financial regulation. ${ }^{124}$ We have already mentioned that the EU history of the completion of an internal market was characterized by minimum harmonization of banking law to enable mutual recognition of banking regulations and home country control of credit

\footnotetext{
${ }^{119}$ Juan Marcheti, Supra note 74 at 286.

${ }^{120}$ Christian Pauletto \& Christoph Köning, 302 "Financial Services in Free Trade Agreements: The Case of Switzerland in Financial regulation at the crossroads implications for supervision, institutional design and trade," (Panagiotis Delimatsis \& Nils Herger eds 2011), Wolters Kluwer Law \& Business.

${ }^{121} \mathrm{Id}$

122 Discussing the convenience of according Mutual Recognition in the context of the Technical Barriers to Trade, Zuñiga considers that the conclusion of these agreements is certainly desirable because, independently of whether technical regulations or standards are harmonized or accepted as equivalent, exporters may be faced with having to test their products in each of the countries they wish to export. Id. at p. 130.

${ }^{123}$ Christian Pauletto \& Christoph Köning, Supra note 120 at 302. The lack of recognition of others, regulatory standards and regulations may be a huge impediment to trade in financial services, as compliance with the different regulatory norms and standards may, from a services suppliers' perspective, for instance lead a huge costs in terms of organization and capital. Thus, unilateral and/or mutual recognition of supervisory rules and regulations may greatly facilitate trade in financial services. Moreover, arrangements on recognition may also enable the supervisory authorities to engage in enhanced cooperation and facilitate the exchange of information with respect to the supervision of financial services suppliers operating on a cross-border basis and in different jurisdictions. Id.

${ }^{124}$ Pierre-Hugues Verdie, Supra note 107 at 97.
} 
institutions. $^{125}$ According to these principles founded in the Second Directive, the authorization for a financial institution to operate in a EU country member is enough for the institution to open branches, or supply financial services, leaving in EU countries of origin prudential supervision, but based on essential harmonization of access to banking activity, capital requirements, solvency ratios, limitations on risk concentration in lending, and standardization of accounting procedures, among others. ${ }^{126}$ However mutual recognition does not require full harmonization; it covers some differences under the understanding (assessment) that home state's regulation is "equivalent" or comparable to that of the state, and vice versa, ${ }^{127}$ and it goes beyond national treatment because private actors can operate in the host state while complying only with the regulatory requirements of their home state. $^{128}$

From previous experience, a deep financial integration project, as announced by the Pacific Alliance instruments, should combine an essential degree of regulatory harmonization duly monitored by a supranational mechanism — with the explicit goal of according mutual recognition, even if some regulatory differences remain. ${ }^{129}$ It will definitively be necessary to create a regional mechanism in the Pacific Alliance to follow the harmonization process and assure it developed sufficiently for extending mutual recognition. For Verdier, this process requires detailed rules and expert monitoring and enforcement after the European experience, where EU institutions played a major role, noting that outside Europe, establishing institutions capable of fulfilling the same functions solely for the purpose of

\footnotetext{
${ }^{125}$ Bart De Meester,Supra note 83 at 271

${ }^{126}$ X. Vives, "Lessons from European Banking Liberalization and Integration” in World Trade Organization and World Bank, The Internationalization of Financial Services - Issues and Lessons for Developing Countries, p. 183 (S. Claessens and M. Jansen eds., 2000 Kluwer Law International).

${ }^{127}$ Pierre-Hugues Verdie, Supra note 107 at 63.

${ }^{128} \mathrm{Id}$.

129 A lesson from other regional integration initiatives is that a sufficient level of legal harmonization is often a precondition for opening financial markets by removing barriers, and for cross-border supervisory cooperation more broadly. In Latin America, initiatives of global regulatory fora (FSB, BCBS) or standards (IFRS) have achieved some, albeit an uneven, degree of legal harmonization in the region. More therefore needs to be done at a regional level, especially to harmonize supervisory rules at a more granular level... Inter-governmental processes should be considered to achieve greater regional harmonization of financial sector legal frameworks, possibly as a precursor to regional "mutual recognition" mechanisms under which host countries grant market access to market participants form home countries that have adopted regionally harmonized rules and practices. IMF, "Financial Integration in Latin America" (Staff Report, March 2016), Supra note 13 at 68.
} 
supporting mutual recognition in financial services is unlikely to be cost-effective. ${ }^{130}$ For that reason, if Pacific Alliance country members take seriously the goal of regional financial integration, it will be decisive to go beyond FTA liberalization standards and create ad hoc schemes to produce a credible harmonization process. We have already mentioned MILA and developments within ASEAN in this regard, but it is also very interesting to consider the progress achieved by the Transatlantic Economic Integration, where in 2007, the U.S. and EU leaders included mutual recognition in securities regulations as part of their goals. ${ }^{131}$

\section{c. Financial Stability and Financial Integration}

Global banking competition has brought benefits to consumers and helped to start modernization $^{132}$ and de-concentration of financial systems in Latin America. It is true that financial systems the Pacific Alliance countries remain highly concentrated. In Peru, the three largest banks account for about 70 percent of bank assets (50 percent in Mexico, Colombia, and Chile). ${ }^{133}$ Additionally, a greater connection to the global economy through all kinds of cross-border transactions may also amplify an intrinsic contagion and spillover risk. Thus, even if there is a consensus that competition in the banking sector increases efficiency in channeling funds from savers to investors, ${ }^{134}$ some authors stress that financial crises have followed capital account liberalization processes in Mexico (1994), East Asia

\footnotetext{
${ }^{130}$ Pierre-Hugues Verdie, Supra note 107 at 79.

${ }^{131}$ Id. at 101.

132 "By expanding possible financing options and vehicles for savings in a country, global financial integration can enhance financial development, which in turn is linked to higher economic growth (Sahay and others, 2015). There are at least three key channels of transmission to growth. First, integration may stimulate capital accumulation through financial deepening in the host country. If capital is brought from outside, competition among financial institutions can be enhanced, particularly when the domestic financial sector contains few institutions and maintains high spreads between borrowing and lending rates; and economies of scale can be exploited by pooling larger amounts of savings. The monetary transmission mechanism can also be enhanced if the banking sector becomes more competitive. All these factors are likely to lower borrowing costs, and stimulate investment. Second, better resource allocation and importation of technology and knowledge may create opportunities for efficiency gains, and boost productivity, which is another source of growth. Third, financial integration can also promote growth indirectly by exposing policy decisions and corporate actions to greater financial market scrutiny." Luc Eyraud, Diva Singh, and Bennett Sutton, Supra note 11 at $21-22$

${ }^{133}$ IMF, "Financial Integration in Latin America, A New Strategy for a New Normal," Supra note 11 at 45 (Preface)

${ }^{134}$ Bart De Meester, Supra note 83 at 1.
} 
(1997), and Russia (1998). ${ }^{135}$ This duality of today’s financial globalization has underlined the explicit responsibility of local regulators to assure national financial stability vis-à-vis external shocks and the concerns about the impact and risks of cross-border transactions over national financial stability at the macro level. Today it is common practice to promote global regulatory cooperation, consolidated supervision, and the adoption of capital and liquidity standards under Basel I, II and III. ${ }^{136}$

The problem is that, while local financial stability and international trade of services go hand-in-hand, in extreme cases protectionist reactions have emerged, like the adoption of regulations that provide liquidity support to domestic but not to foreign financial institutions, ${ }^{137}$ but it is even more significant that risks created by capital flows can be magnified by gaps in countries' financial and institutional infrastructure. Capital flow liberalization is generally more beneficial and less risky if countries have reached certain levels or thresholds of financial and institutional development. ${ }^{138}$

In fact, neither the GATS nor FTAs limit financial regulatory action (as shown by the carve-out exception); nor the multilateral system provides binding rules on financial stability. Therefore, there is a real risk of disconnection between market access rules and financial regulations at the multilateral level, which can be reproduced in regional systems like the Pacific Alliance (which has the explicit goal to integrate financial markets). Once again, this disconnection is reinforced by the fact that Pacific Alliance instruments have reproduced FTA texts under the NAFTA model, without including any guideline or peculiarity about to the integration project. Thus, it will be necessary to find the right balance between liberalization and regulation of financial markets in an appropriate atmosphere of harmonized and monitored local regulations.

\footnotetext{
${ }^{135}$ Luc Eyraud, Diva Singh, and Bennett Sutton, Supra note 11 at 24.

${ }^{136}$ IMF, "Financial Integration in Latin America" (Staff Report, March 2016), Supra note 13 at

${ }^{137}$ Baltensperger and N. Herger, Supra note 24 at 412. These measures could imply the exclusion of local subsidiaries or branches of foreign banks from the access to central bank's emergency liquidity assistance. See, Bart De Meester, Supra note 83 at 102.

138 Davide Furceri and Prakash Loungani, "Capital Account Liberalization and Inequality," 14-15 IMF Working Paper (WP/15/243) 2015.
} 
According to Bart de Meester, if GATS or European principles on free movement of services implied a limitation on national authorities to regulate financial markets, the objective of preserving financial stability would be threatened. This would be equivalent to a situation where GATS or EU law were not able to prevent the creation of barriers to trade banking services, thereby threatening the objective of increasing efficiency in the banking sector. ${ }^{139}$ In fact, local financial stability and market access of foreign banking services can become opposite goals in the absence of a coordination or supranational scheme. In this regard, it is useful to examine the different approaches adopted by local supervisors regarding cross-border transactions of foreign banks' subsidiaries and branches. The supervisor of the country where the bank has been authorized (home country) will be concerned about the soundness of the parent bank, since a failure of the parent will affect the economy in the country of the supervisor. Nevertheless, the activities of the branches and subsidiaries of the parent in other countries are of relevance for the home supervisor. ${ }^{140}$ In fact, the distinction between cross-border banking transactions by means of branches (and mere cross-border supply) and by means of subsidiaries is quite relevant in this respect. ${ }^{141}$ We have seen previously that Mexico requires that the establishment of foreign banks should be made through the constitution of subsidiaries (to diminish the effects from a potential liquidation of the foreign parent company) and several Latin American countries maintain measures that, while increasing the cost of cross-border operations, are fully appropriate in light of the imperative to maintain financial stability ${ }^{142}$ In fact, these types of regulations do not fit well in the context of an integrated or common banking market, as they respond to the unilateral approach of each local supervisor.

\footnotetext{
${ }^{139}$ Bart De Meester, Supra note 83 at 5.

${ }^{140} \mathrm{Id}$. at 48. Danny has even noted that since the recent financial crisis, some host country supervisors have questioned the ability of home country supervisors to supervise foreign branches and to protect the interest of foreign customers. U.K. officials have expressed concern with the principle of home country supervision after the collapse of several Icelandic banks put billions of pounds of deposits made by U.K. residents at risk. Hector Danny, Supra note 109 at 235.

${ }^{141}$ Id at 49.

${ }^{142}$ L. Lorenzo \& W. Bossu, Supra note 66 at 115. Authors cite as examples: limits on intragroup exposures for subsidiaries, local asset maintenance requirement for branches, and the power to ring-fence a local branch of a foreign bank in a nondiscriminatory manner. However, when those measures include excessive or discriminatory characteristics that hinder cross-border integration without yielding meaningful financial stability benefits, they could be modified to better balance financial stability with openness. Ibid.
} 
Lupo-Pasini proposes the EFTA Surveillance Authority v. Iceland case as an example where national financial stability prevailed over the home country control model that had forced Iceland to protect its foreign bank customers. The Court ruled in favor of Iceland, concluding that extending its responsibility to include protection of foreign depositors when the depositor protection scheme is illiquid would jeopardize domestic financial stability. The economic rationale was that, by transferring the liabilities from the private sector to the state, a banking crisis would soon turn into a sovereign debt crisis. ${ }^{143}$ Even considering the special status of Iceland within the European Union, ${ }^{144}$ this case shows that an attempt to protect domestic stability may undermine financial integration principles. ${ }^{145}$ However, these conflicting circumstances are more understandable in FTAs where the goal is liberalization rather than integration. Neither the GATS nor FTAs have binding rules on financial stability or financial harmonization. The GATS prohibits market access restrictions or the adoption of discriminatory measures (it only determines what WTO members cannot do) and encourages mutual recognition. ${ }^{146}$

As has been extensively explained, the carve-out exception is the treaty vehicle that permits the GATS, FTAs, and Pacific Alliance instruments to impose local measures for prudential reasons (including non-discriminatory measures in pursuit of monetary and related credit or exchange rate policies). Prudential reasons are not listed in treaties, but expressed as examples, considering that the corresponding measures are not static: they evolve with the continuing transformation of financial markets. ${ }^{147}$ In fact some WTO members have

\footnotetext{
${ }^{143}$ Federico Lupo-Pasini, Financial Stability in International Law, 18 Melb. J. Int'1 L. 65 (2017)

${ }^{144}$ In fact, Iceland is a member of the European Free Trade Agreement (EFTA) conjointly with Liechtenstein, Norway and Switzerland. EFTA accorded with EU, the Agreement on the European Economic Area, which entered into force on 1 January 1994 implying the application of the rules of common market.

${ }^{145}$ Federico Lupo-Pasini, Supra note 143 at 54.

${ }^{146}$ Bart De Meester, Supra note 83 at 58-59.

147 “...the meaning of 'prudential reasons' is not static, but evolves over time in accordance with the increasing growth, interdependence and complexity of financial activities. For instance, the reforms introduced as a result of the 2008 financial crisis, clearly indicate a qualitative change on the scope of prudential supervision, moving from a system solely focused on monitoring the solvency of individual financial institutions to a macro prudential framework that also emphasizes the need to supervise financial markets generally in order to be able to spot systemic risks that may threaten the stability of the financial system preventatively. This new approach has paved the way for the introduction of a new range of prudential measures aimed at mitigating systemic risks... Gabriel Gari, "GATS Disciplines on Capital Transfers and Short-term Capital Inflows: Time for Change?," 422 Journal of International Economic Law, 2014, 17.
} 
expressed the need to clarify the disciplines affected and specifically whether it covers those adopted to strengthen the stability of the financial system. ${ }^{148}$

In sum, what Lupo-Pasini qualifies as dangerous is the separation between market access and domestic policies, and the general exclusion of financial policies from international legal scrutiny ${ }^{149}$ in the context of the multilateral system. Cottier and Krajewski are even more explicit, suggesting that applying sound prudential standards and thus contributing to the stability of the global financial system is not recognized as a commitment in return for which Members may obtain reciprocal benefits in terms of market access in goods and services of particular interest to them. Could and should the de-linking of Geneva and Basel be overcome ${ }^{150}$ The European Union resolved this potential regulatory conflict by according the European Council (since the Maastricht Treaty) the power to attribute explicit competences to the European Central Bank (ECB) on prudential matters. ${ }^{151}$ This was effectively used after the financial crisis, placing the ECB at the center of macro-prudential policy. Under the Single Supervisory Mechanism Regulation, ${ }^{152}$ the ECB is responsible for adopting macro prudential measures. ${ }^{153}$

Cottier and Krajewski highlight the fact that cornerstone principles of contemporary international trade law, such as the MFN and national treatment principles, are hardly mentioned in the current international financial system. The IMF and the BIS operate basically under soft law mechanisms and not under those anti-discriminatory principles; ${ }^{154}$

\footnotetext{
${ }^{148}$ Id. at 402.

${ }^{149}$ Federico Lupo-Pasini, Supra note 143 at 68. Lupo - Pasini points out that monetary authorities can set the appropriate interest rates and control the level of liquidity in their economy without suffering any legal constraints, and, to a lesser extent, they are free to manage their exchange rate policy. Furthermore, in the context of finance, national supervisors are, in principle, legally free to adopt or ignore international financial standards and to choose when and how to intervene in the event of a local banking crisis. However, the increased pace of economic and financial integration and the closer interdependence among economies achieved in the last few decades has placed in the spotlight the global implications of economic sovereignty that were not visible long ago, and this deserves closer examination. Recent events show that stability and instability are no longer purely domestic matters. Id. at 46-47.

${ }^{150}$ Thomas Cottier and Markus Krajewski, Supra note 118 at 829.

${ }^{151}$ Article 127.6 of the Treaty of the (FUE) Functioning of the European Union.

${ }^{152}$ Council Regulation (EU) No 1024/2013 of 15 October 2013

${ }^{153}$ Article 5 of Council Regulation (EU) No 1024/2013

${ }^{154}$ See Thomas Cottier and Markus Krajewski, Supra note 118 at 819-821. Article I of the Articles of Agreement of the IMF, which refers to the purposes of the IMF, does not include non-discrimination as a key objective of the Fund. Likewise, the general obligations of the Member States towards each other as laid
} 
and the GATS does not require explicitly that prudential measures be applied on a nondiscriminatory basis, even though they should not be used as a means of avoiding members' commitments and obligations. ${ }^{155}$ This circumstance can be precisely explained by the tendency to leave financial stability still in the hands of national competence and subject to general principles.

The potential conflict between market access principles and local financial stability regulations, in the context of the goal of financial integration, should be necessarily addressed as part of the agenda of regulatory cooperation of the Pacific Alliance. In fact, the apparent dilemma between local and global financial stability ${ }^{156}$ may be faced via an integration approach for finding a balance between regulation and liberalization of financial services, such as the European Union is searching for. Since the Treaty of Rome of 1957 ..., the EU has combined liberalization (negative integration) with re-regulation of the banking sector by means of the approximation of laws (positive integration). At the international level, liberalization and possible regulatory convergence are spread over different international bodies (De Meester) ${ }^{157}$

\section{d. Focusing the Agenda for Financial Integration}

As emphasized throughout this article, the construction of a zone of deep integration to develop progressively the free circulation of goods, services, capitals, and persons constitutes the basic peculiarity of the Pacific Alliance, which differs from the liberalization and market access commitments already provided at the multilateral and bilateral level

down in Article IV Section 1 do not explicitly require non-discriminatory treatment. Similarly, neither the Statutes of the BIS nor the Basel Capital Measurement and Capital Standards explicitly refer to nondiscrimination as a guiding principle. Id. at 821

${ }^{155}$ Ibid. at 825. Cottier and Krajewski precise that unlike the Annex on Financial Services, the Understanding on Commitments in Financial Services does include additional elements of non-discrimination such as the application of MFN and national treatment standards on the purchase of financial services by public entities but the Understanding is not part of the single undertaking and mandatory WTO agreements. Id.

${ }^{156}$ Schoenmaker talks about a financial trilemma, where it is impossible to simultaneously achieve national sovereignty over financial stability policies, an optimum level of global financial stability, and meaningful financial integration. He argues that states have to give up one of them, for instance by returning to a situation of reduced financial integration, or by centralizing supervision into a single supranational authority. Federico Lupo-Pasini, Supra note 143 at 66.

${ }^{157}$ Bar de Mester, Supra note 83 at 3 
(GATT, GATS, FTAs and commercial agreements). However, this mark of difference needs to be developed through some specific actions at the treaty and local level, specifically in the area of financial integration. It will be necessary to reinforce the institutional and macroeconomic convergence already reached, consolidate the practice of regulatory cooperation and explore the possibility of some kind of supranational mechanism, which is not alien to Latin American countries in areas such as international human rights. Let us summarize some considerations for the future negotiation agenda.

Reinforcement of institutional and macroeconomic convergence: One of the essential pillars of the Pacific Alliance is the deep level of macroeconomic convergence already achieved among members who share similar approaches to liberalization and open market economy. This converging reality needs to be visible and reflected in instruments geared to reinforce the raison d'être of the project and its own legitimacy. The Preamble of the Framework Agreement expresses members' willingness to make of the Pacific Alliance "a space of agreement and convergence as well as a mechanism of political dialogue",158 and Article 3 considers among its objectives to become "a platform of political articulation." 159 A simple mechanism for putting into immediate practice the declarations and political mandates in a way that is not merely rhetorical is reporting periodically through the Pacific Alliance website the evolution of macroeconomic convergence and the compliance of international financial standards. This sole transparency practice would contribute to monitoring the convergence process already in place by governments and local regulators; and providing to individuals and markets a real perception of the Alliance's potential and possibilities for evolving in different comparative and free controlling mechanisms.

The Pacific Alliance could consolidate comparative statistical information and reports from local regulators, international organizations and soft law creators related to main macroeconomic figures and the compliance of international standards. A global perspective and open scrutiny of each member country's information on IMF article IV reports, Basel standards, and measures for combating money laundering and terrorist financing, among

\footnotetext{
${ }^{158}$ Paragraph 15 of the Preamble of the Framework Agreement.

${ }^{159}$ Article 3 (1) c. of the Framework Agreement.
} 
others, would offer a realistic perspective of the integration process; and, as in other experiences like the European Union, will contribute to building domestic political agendas and attracting the participation of other components of society (academia, civil society, and professional associations) to the discussion and construction of the integration process. In short, the implementation of a simple transparency practice (i.e., consolidating information that is already in the public domain) can contribute considerably to gaining legitimacy and encouraging participation in the process.

Another way to reinforce the convergence already achieved is consecrating the institutional convergence on central bank independence and fiscal responsibility - recognized by all Pacific Alliance members - at the treaty level. Achieving this legal (and eventually constitutional) element will be more complex than our first proposal. However, the idea is not creating either a common currency nor a regional central bank, but establishing —in the Framework Agreement - the principle of central bank independence and the basic elements of fiscal responsibility and transparency already provided by local legislation. The treaty's recognition of those principles and elements will generate a stronger commitment for economic stability in the region and reinforce long-term predictability at the intra- and extra-regional level. For the implementation of this proposal, a fine analysis will be necessary of constitutional and legal provisions in each member country, in order to identify the best possible enunciation of treaty commitments in these areas and facilitate negotiations. It is quite important to consider that central bank independence and consistent economic policies (where fiscal policy today is essential part of State policies) are already constitutive elements of the so called Economic Constitution ${ }^{160}$ which, far from implying a absolutist sovereign competences, guarantee the compliance of economic principles in favour of the exercise of citizens' economic rights.

Regulatory cooperation: In the same line of thought of macroeconomic and institutional convergence, regulatory coordination should support the harmonization process already in place in financial, banking and prudential regulation; and it is advisable to explore the

\footnotetext{
${ }^{160}$ See, MANUEL MONTEAGUDO, LA INDEPENDENCIA DEL BANCO CENTRAL Supra note 25 at 362-364.
} 
possibility of developing this dynamics in new areas, such as monetary and foreign exchange policies. It is more than evident that not only in finance, but also in trade and investment, the degree of integration of Pacific Alliance members is not comparable to the European Union ${ }^{161}$ to the point of justifying common monetary and foreign exchange policies. However, The Pacific Alliance can be another valuable space to exchange policy experiences, as it is already the case in different international and regional forums such as in the IMF, the BIS, the Centro de Estudios Monetarios Latinoamericanos (CEMLA), and in general all soft-law organizations.

Among some specific subjects on prudential and banking regulation that should be addressed in next agendas is the discussion of common rules on the establishment of banks from Pacific Alliance countries [consistency with FTAs already signed], consolidated surveillance of banks established in the region, and cross-border financial services. Another priority that deserves a special place is to start the discussions for defining the roadmap towards a mutual recognition agreement.

IMF recommendations: As already mentioned, the IMF, through preparatory documents, working papers, and comparative research, has been insisting on the need for Latin America, and specifically the Pacific Alliance, to be seriously engaged in financial integration, with some specific recommendations still under discussion. In the context of this contribution, it is worth mentioning some related specifically to the banking sector. For Latin America in general, besides the explicit recommendation to explore opportunities for mutual recognition of licensing, the IMF suggests that all banks have access to credit bureaus and deposit insurance, countries harmonize accounting and regulatory frameworks, through consistent implementation of IFRS, timely adoption of a consistent capital definition as articulated by Basel 3 and Solvency II-type regimes, enhance consolidated supervision of all banking groups, expand supervisory and resolution colleges to cover all regional banks with significant cross-border activity, enhance conglomerate supervision,

\footnotetext{
${ }^{161}$ In the case of Peru its two main commercial partners are Chine and the US that represent $29 \%$ of its commerce, while Mexico, Colombia and Chile represent altogether 7\%. See 2016 Central Bank of Peru Annual Report, p. 42 (http://www.bcrp.gob.pe/docs/Publicaciones/Memoria/2016/memoria-bcrp-2016-2.pdf)
} 
and establish regulatory limits for intra-group exposures within banking groups, and between bank and non-bank parts of conglomerates, and develop explicit, open, objective and non-discriminatory statutory and regulatory framework for entry of foreign financial institutions. $^{162}$

For the Pacific Alliance, the IMF proposes the establishment of a small Secretariat to prepare and disseminate a comprehensive framework for integration, including timelines and sequencing, to align the political and technical agendas, maintain integration momentum, ensure consistency, and gain the benefits of proceeding through reciprocity. ${ }^{163}$ This is interesting, as in many instances Pacific Alliance countries have stressed the fact that the institutional framework of the Alliance should remain informal and straightforward, in contrast with other experiences where the construction of regional bureaucracies has produced endless discussions. In fact, it is time to reinforce the reliability of the integration process of the Pacific Alliance through some level of centralized monitoring. In this regard, it is reasonable to consider creating a small technical unit capable of enhancing the process; otherwise, the process will be determined by the differing paces of progress of local legislators and regulators. A specific IMF regulatory suggestion for the Pacific Alliance refers to the progressive harmonization of safety nets as regards to bank deposit insurance and investor protection, with the possible development of common funds.

At some point, the experience of economic integration will likely make Pacific Alliance countries realize the need to enforce common economic rules, principles and policies. Specifically, it will be necessary to jump from soft to hard law and imagine some sort of supranational regulatory coordination. However, this process should arrive naturally, once regulatory harmonization and actual financial integration have become substantial. However, countries should start making progress towards this possibility through continuing practice of regulatory coordination and exchange of experiences. In fact,

\footnotetext{
${ }^{162}$ IMF, "Financial Integration in Latin America" (Staff Report, March 2016), Supra note at 13.Two other interesting recommendations on the subject are to Explore prospects for revitalizing regional currency settlement/Work towards full compliance with FATF standards so as to avoid loss of correspondent banking relationships; integrate efforts, including on plans to mitigate corresponding banking issue, across the region. Ibid

${ }^{163}$ Id. at $14,76$.
} 
supranational mechanisms are not alien to Latin America, if we consider the consolidation of the Inter-American Human Rights System, in place during the last 50 years and evolving towards new areas, such as economic rights (FTAs, CAN, and other experiences).

\section{CONCLUSION}

Pacific Alliance member countries have reached such a level of macroeconomic stability and convergence (even before the formal constitution of the alliance) that it is reasonable to expect new forms of economic and institutional evolution in the region. In light of other experiences like the European Union, a likely path is building a deep financial integration area, as generally enunciated in treaty instruments (in fact a necessity, due to the withdrawal of major global banks from the region). However, there are no explicit provisions or guidelines for the commitment of financial integration, because most articles in the Framework Agreement and Additional Protocol mirror FTA texts under the NAFTA model (following FTA agreements signed by member countries with the U.S.). The real challenge for the Alliance is to unleash those energies and commitments towards financial integration that remain implicit in texts and deserve an extensive work of harmonization and regulatory coordination. Financial integration is not a mere liberalization and market access code that is being replicated at the bilateral level; it is in fact part of a major project to consolidate an area of regional integration. Harmonization of prudential rules, mutual recognition and financial stability principles designed with a regional approach are basic elements of future agendas that should be complemented with a decisive effort to bring to the treaty level the institutional convergence on central bank independence and fiscal responsibility. 